RAFAEL DOMINGOS FAIARDO VANZELLA

\title{
NUMERUS CLAUSUS DOS DIREITOS REAIS E AUTONOMIA NOS CONTRATOS DE DISPOSIÇÃO
}

\author{
Tese de doutorado em direito civil, sob a \\ orientação do Professor Doutor Alcides \\ Tomasetti Júnior.
}

Faculdade de Direito da Universidade de São Paulo

São Paulo, 15.I.2009 


\section{INTRODUÇÃO}

“Quer-se pouco compreender como o contrato, se há de ter uma eficácia exclusivamente pessoal [sic], é insuficiente para a tutela da circulação. As necessidades dessa última exigem que ao donatário, ao comprador, ao locatário, ao sócio, ao cessionário seja garantido o gozo dos bens, nos limites do contrato; ora, se diante das moléstias ou das resistências de terceiros, cada um daqueles não pudesse senão se voltar ao seu contratante a fim de que ele as fizesse cessar ou, se não o conseguisse, ressarcisse-lhe o dano, e, eventualmente, o contrato se resolvesse, aquelas necessidades seriam em grande parte insatisfeitas".

Dessa advertência do gênio de F. CARNELUTTI ${ }^{1}$, é razoável inferir que, nas múltiplas relações de intercâmbio de bens econômicos de que participam, e para cuja modelagem tenham optado por técnicas jurídicas de provimento desses mesmos bens ${ }^{2}$, os agentes privados invariavelmente almejam extrapolar os limites ético-jurídicos $d a$ contratualidade $^{3}$. É dizer, se existe um princípio nos ordenamentos jurídicos contemporâneos, segundo o qual as pessoas afetadas pelos efeitos dos negócios jurídicos têm de haver colaborado na sua formação ${ }^{4}$ - daí as idéias de autonomia privada e de contrato $^{5}$-, os interesses econômico-sociais típicos, em sede de circulação, impõem, as mais das vezes, que também terceiros - isto é, pessoas que não tomaram parte na formação daqueles mesmos negócios - estejam, de alguma forma, vinculados pelos efeitos negociais, e que seus próprios interesses submetam-se igualmente a tais efeitos. M. WEBER também

Teoria giuridica della circolazione. Padova: CEDAM, 1933, p.46.

V. $\S 3^{\circ}$, tít. 7, infra.

Cf. F. BYDLINSKI. Privatautonomie und objektive Grundlagen des verpflichtenden Rechtsgeschäftes. Wien: Springer, 1967, p.66-70; O. BEHRENDS. Die rechtsethischen Grundlagen des Privatrechts. In: F. BYDLINSKI, T. MAYER-MALY (hrsg.). Die ethischen Grundlagen des Privatrechts. Wien: Springer, 1994, p.1-33.

4 W. FLUME. Allgemeiner Teil des bürgerlichen Rechts: Das Rechtsgeschäft. 3. ed. Berlin: Springer, 1979, p.136-7. Boa parte das citações dessa obra está apoiada na versão espanhola: W. FLUME. El negocio jurídico. Trad. de J. M. Miquel González e E. Gómez Calle. Madrid: Fundación Cultural del Notariado, 1998.

5 "O princípio da autonomia privada não confere nenhuma legitimação para atuar autarquicamente para outros. Entretanto, como regra geral, por uma relação jurídica, várias pessoas ficam vinculadas. Por isso, a configuração autônoma de relações jurídicas necessita, por regra geral, da colaboração de várias pessoas, concretamente daquelas que se vinculam pela relação jurídica. A idéia de contrato é que o acordado contratualmente tem validez porque os contratantes, cada um em uso de sua autodeterminação, estipularam o que deve ser direito (...). Com toda segurança, é certo que, no contrato, os interesses opostos se garantem reciprocamente pelos contratantes" (W. FLUME. Allgemeiner Teil des bürgerlichen Rechts: Das Rechtsgeschäft. 3. ed. Berlin: Springer, 1979, p.7). 
o assinalou: "Como regra geral [sic], os negócios jurídicos incluem um poder de os contratantes acometerem até mesmo terceiros" $"$.

Uma das mais representativas modalidades de tutela jurídica dessa exigência de heteronomia privada é a transmissão contratual das posições jurídicas subjetivas patrimoniais disponíveis, sejam obrigacionais, sejam reais. $\mathrm{Na}$ medida em que se reconhece, por princípio, a precedência do titular - ou proprietário, em sentido amplíssimo $^{7}-$ da posição jurídica subjetiva patrimonial disponível sobre quaisquer outros títulos que, direta ou indiretamente, refiram-se à mesma posição (nemo plus iuris transferre potest quam habet ipse ${ }^{8}$; nemo dat quod non habet ${ }^{9}$ ), uma clássica - embora não única - técnica de submissão de interesses econômico-sociais de terceiros a interesses econômico-sociais dos contratantes é o tipo de contrato cujo objeto consista na transmissão das posições jurídicas subjetivas patrimoniais disponíveis; isto é, na perda, total ou parcial, de uma posição jurídica subjetiva patrimonial disponível, obrigacional ou real, pelo antigo titular e a correlata aquisição, correspondentemente total ou parcial, da mesma posição pelo novo titular. Esse tipo de contrato é o contrato de disposição ${ }^{10}$.

Nenhum outro tipo de contrato implica alteração da titularidade das posições jurídicas subjetivas patrimoniais disponíveis. Mediante a celebração de contratos obrigacionais, transferem-se bens econômicos, mas as posições jurídicas subjetivas patrimoniais disponíveis sobre esses bens não se transmitem ${ }^{11}$. O status de atribuição preexistente, no mundo do direito, permanece absolutamente intocado.

\footnotetext{
Economy and Society: An Outline of Interpretive Sociology. Trad. de G. Roth e C. Wittich (coords.). Berkeley: University of California, 1978, p.684, v.2.

V. $\S 3^{\circ}$, tít. 6 , infra.

Cf. F. C. PONTES DE MIRANDA. Tratado de direito privado. Rio de Janeiro: Borsoi, 1955, p.26, v.5. Cf. I. TOSI. Acte translatif et titularité des droits. Paris: LGDJ, 2006, p.17.

V. cap. III, infra.

1 Visando à harmonia terminológica, estipula-se que transferência consiste no deslocamento de bens econômicos que se opera no mundo dos fatos, tal como a transferência da posse, a transferência de energias e forças humanas pelo desempenho de comportamentos etc; transmissão, no deslocamento de posições jurídicas subjetivas patrimoniais disponíveis, o que supõe mudança de titularidade e, por conseqüência, perda e, correlatamente, aquisição de posições jurídicas subjetivas patrimoniais disponíveis, obrigacionais ou reais, simples ou complexas, ativas ou passivas. Transmissão é gênero de que são espécies as figuras da cessão, da alienação, da sub-rogação pessoal, da sucessão, dentre outras, que podem apresentar, entre si, e no pormenor, diferenças sutis, nem sempre tratadas coerentemente no direito positivo. Cf. J. M. ANTUNES VARELA. Direito das obrigações. Rio de Janeiro: Forense, 1978, p.300-1 e 303-5, v.2; v. § $9^{\circ}$, infra.
} 
Se assim é, quem quer que decida tornar-se titular de uma posição jurídica subjetiva patrimonial disponível cuja transmissão ou cujo exercício tenham sido meramente prometidos, ainda que positivamente saiba dessa promessa, poderá adquiri-la e, mais do que isso, poderá, ao menos em princípio, subjugar os interesses econômico-sociais do credor da promessa a seus próprios interesses ${ }^{12}$. Pois o credor não é titular da preexistente posição jurídica subjetiva patrimonial disponível transmitida. Por meio do contrato obrigacional, ele se tornou titular de uma posição jurídica subjetiva patrimonial ativa original - o crédito - que lhe confere pretensão à transmissão ou ao exercício de fato da posição jurídica subjetiva patrimonial disponível preexistente. Não se lhe conferiu a própria posição jurídica subjetiva patrimonial disponível preexistente ou o seu próprio exercício. Ele não é, ao menos ainda, proprietário (em sentido amplíssimo); ele não é, ao menos ainda, titular da posição jurídica subjetiva patrimonial disponível na qual seus interesses econômico-sociais recaem. Não houve transmissão. A eficácia jurídica é bastante outra. Da mesma maneira, quem quer que decida precaver-se da transmissão, contratual ou não, de uma posição jurídica subjetiva patrimonial disponível, de modo a preferir nessa mesma virtual e ulterior transmissão, deve, o quanto antes, adquirir essa mesma posição, total ou parcialmente. Todos os adquirentes posteriores, ou porque "adquiriram" a non domino, ou porque não a adquiriram plenamente, terão seus interesses econômico-sociais preteridos em favor do primeiro adquirente.

Não só os terceiros-adquirentes são terceiros potencialmente afetados pela celebração de contratos de disposição. En fait des meubles la possession vaut tître ${ }^{13}$. Em razão dessa regra, reconhecida com maior ou menor amplitude pela maior parte dos ordenamentos jurídicos contemporâneos, os próprios titulares - e, por consequiência, seus respectivos credores - podem ter seus interesses econômico-sociais preteridos em favor da parte de contratos de disposição que figura na posição de adquirente. Nas situações de cisão entre titularidade e posse direta de bens móveis, é a vez do titular se submeter a manifestações de heteronomia privada, perdendo seu posto independentemente de sua colaboração na formação do contrato de disposição que tem por objeto a transmissão de sua própria posição jurídica subjetiva patrimonial.

12 L. ENNECCERUS, H. C. NIPPERDEY. Allgemeiner Teil des bürgerlichen Rechts. 15. ed. Tübingen: J. C. B. Mohr, 1960, p.891-2, v.2; A. TUHR. Der allgemeine Teil des deutschen bürgerlichen Rechts. Leipzig: Duncker \& Humblot, 1957, p.369-70, v.2, t.1; K. H. SCHWAB, H. PRÜTTING. Sachenrecht. 32. ed. München: C. H. Beck, 2006, p.1.

13 Art. 2279 Code Civil. 
Por isso, não é despropositado afirmar que repousa sobre as transmissões contratuais, translativas ou constitutivas ${ }^{14}$, um verdadeiro interesse público. Não no sentido de um interesse do estado, conquanto, não raro, essas transmissões, tomadas como suporte fático de normas jurídicas tributárias, também lhe toquem. No sentido, todavia, de que essas mesmas transmissões, embora causadas pelo consentimento jurídico-negocial declarado de agentes privados determinados, acometem potencialmente os interesses econômico-sociais de um conglomerado indeterminado de outros agentes. Paralelamente à sua fase de autonomia privada, no plano da existência, há outra, de heteronomia privada, no plano da eficácia. Quer dizer, os contratos de disposição, apesar de seguirem algumas das mesmas regras de formação de todo e qualquer outro contrato, constituem efeitos jurídicos, ao menos potencialmente, para além de suas partes.

Não por acaso, destarte, a irradiação dos efeitos jurídicos dos contratos de disposição - isto é, a própria transmissão - subordina-se sempre a uma divulgação, a uma notoriedade (Offenkundigkeit $)^{15}$. No dizer de F. CARNELUTTI, a um "indice della circolazione": "não basta, para o contrato, ser, precisa também parecer"16. A fim de tutelar aquele interesse público, as transmissões contratuais, translativas ou constitutivas, das posições jurídicas subjetivas patrimoniais disponíveis nunca se operam sem a observância de alguma "forma" de publicidade, isto é, um procedimento pelo qual o contrato de disposição se identifique, ademais, como um evento fático exterior e visualmente apreensível $^{17}$. Esse procedimento pode ser a simples tomada-entrega da posse, isto é, a tradição, em sentido estritíssimo, ou ficta (CC, arts. 904, 910, § 2º 1.226, 1.267, caput e parágrafo único). Por vezes, o registro de um documento (CC, arts. 221, 922, 1.003, 1.057, parágrafo único c.c. 999 , parágrafo único, 1.227, 1.432, 1.438, 1.448, 1.452, 1.462; Lei 9.279/96, arts. 59, I e II c.c. 60, 121, 136, I e II c.c. 137, 211). Ou ainda, a simples instrumentação do contrato, solene (Lei 6.404/76, arts. 31, parágrafo primeiro, e 35, parágrafo primeiro) ou meramente especial (CC, art. 288; Lei 9.610/98, art. 50) ${ }^{18}$. Enfim, a notificação dos interessados (CC, art. 290).

\footnotetext{
V. $\S 9^{\circ}$, infra.

K. H. SCHWAB, H. PRÜTTING. Sachenrecht. 32. ed. München: C. H. Beck, 2006, p.14; H. WESTERMANN et alii. Sachenrecht: Ein Lehrbuch. 7. ed. Heidelberg: C. F. Müller, 1998, p.18-9.

Teoria giuridica della circolazione. Padova: CEDAM, 1933, p.62 (grifos no original).

F. BAUR, J. F. BAUR, R. STÜRNER. Sachenrecht. 17. ed. München: C. H. Beck, 1999, p.31-2.

Observe-se que se trata de forma do negócio jurídico como fator de eficácia, e não como o requisito de validade disciplinado nos arts. 104, III, e 166, IV e V, CC.
} 
A publicidade é, destarte, fator de eficácia - ora simples, ora relativa ${ }^{19}-$ dos contratos de disposição. Não há transmissão contratual, translativa ou constitutiva, das posições jurídicas subjetivas patrimoniais disponíveis sem publicidade. Isso não é apenas um princípio do direito das coisas (CC, arts. 1.196 a 1.510). Núcleo da ordem jurídica da circulação econômica, isto é, do direito patrimonial privado, uma organização jurídica da atribuição dos bens econômicos extravasa o livro III da parte especial do $\mathrm{CC}^{20}$, muito embora seja nele que se concentram as regras que disciplinam paradigmaticamente o fenômeno jurídico da atribuição patrimonial por transmissão ${ }^{2122}$.

Apenas a publicidade, entrementes, não seria eficiente para eqüiponderar a exposição à heteronomia privada que sofrem os interesses econômico-sociais de terceiros em razão da permissão legal de celebração de contratos de disposição. Na publicidade, há muitas falhas.

De um lado, há as deficiências dos procedimentos de publicidade, e a transferência da posse é, disso, o exemplo mais representativo. Com efeito, abundam os casos de possuidores que não são, simultaneamente, titulares da propriedade da coisa possuída; e, muitas vezes, sequer têm um título para a sua posse. Como o direito positivo só cum granu salis ${ }^{23}$ incorporou a regra en fait des meubles la possession vaut tître (art. 1.268, segunda parte, CC), não existe grande segurança em se contratar com o possuidor, se o fim é o de adquirir posições jurídicas subjetivas reais, a não ser nesses últimos e naqueles casos em que a lei determina o registro do instrumento contratual que embasa a transferência da posse, e esse último não tenha sido efetuado por quem tem o respectivo ônus (arts. 522, 1.361, § $1^{\circ}, 1.432,1.438,1.448,1.462$ CC). Aliás, o registro serve, nesses

19 Cf. A. JUNQUEIRA DE AZEVEDO. Negócio jurídico: Existência, validade e eficácia. 4. ed. São Paulo: Saraiva, 2002, p.52-8.

20 Cf. H. WESTERMANN et alii. Sachenrecht: Ein Lehrbuch. 7. ed. Heidelberg: C. F. Müller, 1998, p.8.

21 V. cap. III, esp. $\S 9^{\circ}$, infra.

22 Expressiva, nesse sentido, a análise de T. ASCARELLI, para quem a regulação dos títulos de crédito é resultante de um processo de assimilação da disciplina do direito das coisas, já que, naquela matéria, "[o] direito acaba por ficar plenamente objetivado e despersonalizado, por ser considerado um bem, um valor, como tal, exatamente definido e delimitado, distinto da relação econômica de que se originou e submetido, portanto, às regras da circulação dos bens móveis" (Teoria geral dos títulos de crédito. 2. ed. Trad. Nicolau Nazo. São Paulo: Saraiva, 1969, p.11).

23 Em sentido contrário, F. C. PONTES DE MIRANDA: “[e]m nenhuma regra do Código Civil (...) há a regra En fait de meubles, possession vaut tître. Só o direito cambiário e cambiariforme recebeu, através da teoria alemã do título cambiário, a aquisição da propriedade pela posse de boa fé" (Tratado de direito privado. Rio de Janeiro: Borsoi, 1955, p.223, v.14, sem grifos no original). 
casos, como contrapeso à aparência de titularidade que é gerada pela posse, mas não há uma regra geral que determine o registro do instrumento contratual em todos os casos de cisão entre titularidade e posse direta. Exemplos emblemáticos são as situações de flagrante insegurança daquele que "adquire" - fora da hipótese do art. 1.268, segunda parte, CC - de possuidor direto usufrutuário ou usuário de coisas móveis, ou do comodatário ou do depositário. "Adquire" a non domino e sem nenhuma tutela legal, senão o remédio do art. $389 \mathrm{CC}$, se houver, e na medida em que o permitir, o negócio jurídico basal (obrigacional).

De qualquer maneira, sente-se já, por aqui, a necessidade de uma pauta de orientação, tanto dos titulares quanto dos adquirentes, quanto mais rudimentares se caracterizarem os procedimentos de publicidade a que se subordina a eficácia dos contratos de disposição. O pressuposto é uma regra de concerto para uma nítida questão distributiva: ou se desconsideram os efeitos extramuros das manifestações de autonomia dos titulares, e sacrificam-se os interesses econômico-sociais desses últimos; ou se os consideram, e sacrificam-se os interesses econômico-sociais dos terceiros-adquirentes ${ }^{24}$. A opção pela promoção de ambos os núcleos de interesses econômico-sociais, em permanente conflito, enseja um problema de informação e, com ele, uma nova questão distributiva. Ou se impõe o ônus de informar aos titulares, e os custos seriam insuportáveis, visto que, em um direito patrimonial privado promotor do tráfico, infinitos são os potenciais adquirentes; ou se impõe o ônus de obter a informação aos adquirentes, e novamente os custos seriam insuportáveis, visto que, em um direito patrimonial privado assegurador da autonomia do titular, infinitas são as possibilidades de pactos estipuláveis sobre o status de atribuição das posições jurídicas subjetivas patrimoniais disponíveis ${ }^{25}$ : a criatividade da iniciativa privada não tem fronteiras; a imaginação dos agentes privados ultrapassa as raias do verossímil; as idiossincrasias são imponderáveis; torna-se, então, virtualmente impossível aos terceirosadquirentes diligenciar sobre o status de atribuição das posições jurídicas subjetivas patrimoniais disponíveis, dado que, senão ao acaso e à aleatoriedade, ninguém pode achar nada sem saber, de antemão, aquilo pelo que procura. A opção pela distribuição do ônus da informação leva à elaboração de dois standards de conduta: comporta-se como bonus pater familias tanto o adquirente que busca a informação sobre o status de atribuição da posição

24 Cf. T. MERRILL, H. SMITH. Optimal Standardization in the Law of Property: The Numerus Clausus Principle. In: Yale Law Journal 110, 2000, p.26-38.

25 Cf. C. BERGER. Rechtsgeschäftliche Verfügungsbeschränkungen. Tübingen: Mohr Siebeck, 1998, p.87. 
jurídica subjetiva patrimonial disponível a ser adquirida quanto o titular que cuida da publicidade de suas declarações jurídico-negociais sobre sua própria posição jurídica subjetiva patrimonial disponível.

Ora, a idéia de um numerus clausus, em geral, aparece, aqui, como uma das manifestações do processo de simplificação analítica $^{26}$, marca evolutiva do direito ocidental $^{27}$ : um catálogo legalmente predeterminado e juridicamente fixo, isto é, um numerus clausus dos pactos - não só os de disposição - que devem ser publicados para serem "oponíveis" concorre para a observância dos procedimentos de publicidade, na medida em que esses últimos pressupõem uma "estandardização implícita", isto é, uma definição dos pactos que se sujeitam a eles para surtir certos efeitos e que pertençam, assim, a um gênero limitado. Da mesma maneira, um numerus clausus dos pactos - não só os de disposição - que submeterão eficazmente os interesses econômico-sociais dos terceiros-adquirentes auxilia, deveras, a investigação. Explica-se, destarte, aquilo pelo que se deve diligenciar e assegura-se que quaisquer pactos que não se subsumam aos esquemas legais, predeterminados, não serão "oponíveis" 28 . Mais do que facilitar a publicidade e a investigação - isto é, a oferta e a obtenção de informação - e também por isso, aquele catálogo garante a segurança da orientação (Orientierungssicherheit), a qual, como adverte H. HENKEL ${ }^{29}$, é um dos aspectos essenciais do princípio da segurança jurídica (Rechtssicherheit), corolário do estado de direito.

Por outro lado, há as insuficiências dos procedimentos de publicidade. $\mathrm{Na}$ verdade, se todos os titulares de posições jurídicas subjetivas patrimoniais disponíveis tivessem ampla liberdade para celebrar contratos de disposição, e ainda que dessem a esses

26 Cf. R. VON JHERING. Geist des römischen Rechts auf den verschiedenen Stufen seiner Entwicklung. 7. ed. Leipzig: Breitkopf und Härtel, 1926, p.133-4, 292-3, v.2, t.1.

27 Cf. M. WEBER. Economy and Society: An Outline of Interpretive Sociology. Trad. de G. Roth e C. Wittich (coords.). Berkeley: University of California, 1978, p.672, v.2.

28 Cf. B. FÖ̈X. Les "numerus clausus" des drois réels en matière mobilière. Lausanne: Payot, 1987, p.27; J. PENNER. The Idea of Property in the Law. Oxford: Oxford University Press, 1997, p.23.

29 Einführung in die Rechtsphilosophie: Grundlagen des Rechts. München: C. H. Beck, 1964, p.335-6: "pode-se caracterizar a determinabilidade do conteúdo dos direitos como segurança da orientação: o homem quer saber como tem de se comportar conforme lhe exigem os direitos em determinadas situações vitais ou relações sociais; qual comportamento pode esperar e exigir do outro; quais direitos e deveres existem e com quais conseqüências de seu comportamento tem de contar. $\mathrm{O}$ significado fundamental dessa segurança da orientação para o homem, especialmente o homem econômico, instruído pela auto-orientação na vida, não requer maior demonstração"; assim, "em atenção a cada norma jurídica, corresponde à exigência de segurança jurídica a determinabilidade tanto do suporte fático quanto das conseqüências jurídicas". 
últimos vasta publicidade, pactos que fragmentam a titularidade $^{30}$ poderiam, independentemente de previsão legal, ser estipulados. A conseqüente irradiação de vários títulos de precedência sobre um mesmo direito subjetivo patrimonial comprometeria gravemente princípios estruturais da ordem jurídica da circulação econômica, isto é, o direito patrimonial privado. Primeiramente, seria heteronomamente configurável a capacidade de adquirir $^{31-32-33}$, que é manifestação essencial da personalidade ${ }^{34}$. Caberia, nesse sentido, a declarações jurídico-negociais ("autônomas") um amplo poder de heterodeterminação, a ser exercido a líbito pelos titulares contra um conglomerado indeterminado de potenciais adquirentes. A autonomia contratual transbordar-se-ia sem reservas em sacrifício de aspectos do direito geral de personalidade, por um lado, e heteronomia privada, por outro lado, e a axiologia dos ordenamentos jurídicos contemporâneos teria de ser completamente reconsiderada. Além disso, todos os titulares

30 Cf. M. HELLER. The boundaries of private property. In: Yale Law Journal 108, 1999, p.1187-202; C. BERGER. Rechtsgeschäftliche Verfügungsbeschränkungen. Tübingen: Mohr Siebeck, 1998, p.13. Na concepção desse último autor, esse divórcio é, por si, um problema. Não tem razão. O problema é a falta de previsão legislativa para esse divórcio.

31 "O poder de aumentar o próprio patrimônio mediante a aquisição de direitos pode ser designado como poder de adquirir [Erwerbsmacht]"; trata-se de "uma manifestação da capacidade jurídica [Rechtsfähigkeit]" (L. ENNECCERUS, H. C. NIPPERDEY. Allgemeiner Teil des bürgerlichen Rechts. 15. ed. Tübingen: J. C. B. Mohr, 1960, p.892, v.2).

32 Em sentido contrário, C. BERGER, para quem restrições ao poder de dispor não afetam o poder de adquirir; cambaleante, já que reconhece essa mesma eficácia aos direitos subjetivos reais (Rechtsgeschäftliche Verfügungsbeschränkungen. Tübingen: Mohr Siebeck, 1998, p.79, n.11).

33 V. $\$ 5^{\circ}$, tít. 13 , infra.

34 Para além das questões de transparência e segurança jurídicas, a idéia desenvolvida consiste essencialmente na "expressão do pensamento de que a livre disposição sobre o patrimônio é um atributo incondicional do sujeito de direito"; recai, "assim, no campo da inviolável dignidade humana e dos direitos de livre desenvolvimento da personalidade" (F. BAUR. Enneccerus-Nipperdey: Allgemeiner Teil des bürgerlichen Rechts. In: Juristenzeitung, 1961, p.335). No mesmo sentido, C. CROME. System des deutschen bürgerlichen Rechts. Tübingen: Mohr, 1900, p.379, v.1; J. VON STAUDINGER, J. KOHLER. J. von Staudingers Kommentar zum Bürgerlichen Gesetzbuch mit Einführungsgesetz und Nebengesetzen: Allgemeiner Teil $\$ \S$ 134-163. Berlin: Sellier-de Gruyter, 2003, p.188, v.4; H. T. SOERGEL, W. HEFERMEHL. Kommentar zum BGB: Allgemeiner Teil \$§ 104-240. 13. ed. Stuttgart: Kohlhammer, 1999, p.233; O. PALANDT et alii. Bürgerliches Gesetzbuch. 67. ed. München: C. H. Beck, 2008, p.126; G. KRÜGER-NIELAND, H. ZÖLLER. Das BGB mit besonderer Berücksichtigung der Rechtsprechung des Recihsgerichts und des Bundesgerichtshofes (RGR Kommentar): \$\$ 1-240. 12. ed. Berlin: Walter de Gruyter, 1982, p.64-5; R. LIEBS. Die unbeschränkbare Verfügungsbefugnis. In: Archiv für die civilistische Praxis 175, 1975, p.39; B. GROßFELD, H. G. GERSCH. Zeitliche Grenzen von privaten Schuldverträgen. In: Juristenzeitung 43, 1988, p.944; H. SCHLOSSER. Außenwirkungen verfügungshindernder Abreden bei der rechtsgeschäftlichen Treuhand. In: Neue juristische Wochenschrift 23.1, 1970, p.681; A. RAIBLE. Vertragliche Beschränkung der Übertragung von Rechten: Eine Untersuchung zum Verhältnis von $\$ 413,399$ 2. Alt. BGB zu 1137 Satz 1 BGB. Tübingen: Mohr, 1969, p.77; P. SEIFERT. Verfügungsfreiheit und rechtsgeschäftliches Veräußerungsverbot. Frankfurt am Main: Rechtswissenschaftliche Fakultät, 1966, p.75, 97; D. MEDICUS. Allgemeiner Teil des BGB: Ein Lehrbuch. 6. ed. Heidelberg: C. F. Müller, 1994, p.249-50; H. WEITNAUER. Die unverzichtbare Handlungsfreiheit. In: E. BÖKELMANN et alii. Festschrift für Friedrich Weber zum 70. Geburtstag. Berlin: Walter de Gruyter, 1975, p.429; G. KEGEL. Nemo ,minus' iuris transferre potest, quam ipse habet, oder warum Erbteilungsverbote so kraftlos sind. In: G. WARDA et alii. Festschrift für Richard Lange zum 70. Geburtstag. Berlin: Walter de Gruyter, 1976, p.936-40; P. BÜLOW. Grundfragen der Verfügungsverbote. In: Juristische Schulung, 1994, p.4. 
de posições jurídicas subjetivas patrimoniais poderiam livremente comprometer a disponibilidade dessas mesmas posições. O engessamento dos sistemas, de lege lata, de satisfação dos credores seria um resultado fatal: porque as execuções judiciais se assentam na alienabilidade das posições jurídicas subjetivas patrimoniais submetidas ao aparato jurisdicional coercitivo (arts. 591, 648, 649, I, CPC) ${ }^{35}$, caberia aos agentes privados, e não ao legislador - quer dizer, aos contratos, e não à lei - uma ampla disciplina sobre a penhorabilidade $e^{36}$. Na mesma toada, na medida em que as execuções concursais baseiamse em uma ordem de recebimento que reconhece títulos de precedência - entre eles os direitos subjetivos reais (art. $958 \mathrm{CC}$; art. 83 Lei 11.101/05) - caberia às partes dos contratos de disposição, autonomamente, um poder de reclassificar os chamados "créditos preferenciais" 37 .

Conseqüentemente, na medida em que, em uma ordem jurídica de livre circulação econômica $^{38}$, (i) o status de atribuição das posições jurídicas subjetivas patrimoniais disponíveis tem por pressuposto a uniformidade; e (ii.a) todos os agentes privados são captados como potenciais adquirentes de posições jurídicas subjetivas patrimoniais e (ii.b) essas mesmas posições conformam-se legalmente como

35 É o que F. C. PONTES DE MIRANDA chama de "princípio de paralelismo da transferibilidade [sic] $e$ da constringibilidade" (Tratado de direito privado. Rio de Janeiro: Borsoi, 1955, p.332, v.5).

36 Cf. P. BÜLOW. Grundfragen der Verfügungsverbote. In: Juristische Schulung, 1994, p.4; E. WAGNER. Rechtsgeschäftliche Unübertragbarkeit und \$ 137 S. 1 BGB. In: Archiv für die civilistische Praxis 194, 1994, p.451-60; R. WANK. Mißbrauch der Treuhandstellung und der Vertretungsmacht. In: Juristische Schulung, 1979, p.403; A. RAIBLE. Vertragliche Beschränkung der Übertragung von Rechten: Eine Untersuchung zum Verhältnis von $\S$ 413, 399 2. Alt. BGB zu $\$ 137$ Satz 1 BGB. Tübingen: Mohr, 1969, p.73; M. WIESMANN. Zur Tragweite des § 137 BGB. Münster: Westfälischen Wilhelms-Universität, 1991, p.36; J. KOHLER. Das Verfügungsverbot gemäß $\$ 938$ Abs. 2 ZPO im Liegenschaftsrecht: Eine Untersuchung zum System der Immobiliarrechtssicherung. Köln: Heymanns, 1984, p.315; W. ERMAN, H. P. WESTERMANN, H. PALM. Bürgerliches Gesetzbuch: Handkommentar. 12. ed. Köln: Dr. Otto Schmidt, 2008, p.388; J. VON STAUDINGER, J. KOHLER. J. von Staudingers Kommentar zum Bürgerlichen Gesetzbuch mit Einführungsgesetz und Nebengesetzen: Allgemeiner Teil §§ 134-163. Berlin: Sellier-de Gruyter, 2003, p.191-2, v.4; W. FLUME. Allgemeiner Teil des bürgerlichen Rechts: Das Rechtsgeschäft. 3. ed. Berlin: Springer, 1979, p.362-3; R. LIEBS. Die unbeschränkbare Verfügungsbefugnis. In: Archiv für die civilistische Praxis 175, 1975, p.12, 23, 36; G. FURTNER. Die rechtsgeschäftliche Verfügungsbeschränkung und ihre Sicherung. In: Neue juristische Wochenschrift 19.1, 1966, p.185; B. GROßFELD, H. G. GERSCH. Zeitliche Grenzen von privaten Schuldverträgen. In: Juristenzeitung 43, 1988, p.944; W. TIMM. Außenwirkungen vertraglicher Verfügungsverbote? In: Juristenzeitung 44.1, 1989, p.17; H. WIEDEMANN. Die Übertragung und Vererbung von Mitgliedschaftsrechten bei Handelsgesellschaften. München: C. H. Beck, 1965, p.184; W. DÄUBLER. Rechtsgeschäftlicher Ausschluß der Veräußerlichkeit von Rechten? In: Neue juristische Wochenschrift 21.1, 1968, p.1117; H. SCHLOSSER. Außenwirkungen verfügungshindernder Abreden bei der rechtsgeschäftlichen Treuhand. In: Neue juristische Wochenschrift 23.1, 1970, p.683; C. ARMBRÜSTER. Münchener Kommentar zum Bürgerlichen Gesetzbuch: Allgemeiner Teil §§ 1-240. 5. ed. München: C. H. Beck, 2006, p.1633, v.1.1.

37 Cf. referências citadas na nota anterior.

38 N. IRTI. L'ordine giuridico del mercato. 4. ed. Roma: Laterza, 2001, p.38-44. 
“mercadorias" "39, uma reserva de lei para a configuração da titularidade ${ }^{40}$ e uma garantia institucional $^{41}$ para os princípios, respectivamente sobrejacentes, da capacidade jurídica e da res in commercium $^{42}$ são, simplesmente, indeclináveis. Essa reserva de lei e essa garantia institucional consistem, precisamente, no regime de numerus clausus dos contratos de disposição ${ }^{43}$.

Esse regime jurídico se identifica, negativamente, por uma conformação drasticamente limitada da autonomia contratual, em comparação com a autonomia nos contratos obrigacionais. Com efeito, as partes dos contratos de disposição só podem (i) decidir, previamente, entre celebrar ou não celebrar contrato de disposição; (ii) se decidirem por celebrar, escolher algum dos tipos em espécie de contratos de disposição predispostos pelo ordenamento legal; e (iii) modelar as regras dispositivas (não cogentes) presentes no tipo escolhido, na medida em que o permitir o ordenamento legal. Todas as declarações jurídico-negociais que não se enquadrarem nesses esquemas não "gravam" adversus omnes o direito subjetivo patrimonial a que se referem, conquanto possam subsistir juridicamente como negócios jurídicos obrigacionais, com a consequiência prática de que terceiros não serão, em princípio, afetados por eles, ainda que conheçam

39 “A expressão 'mercadoria' (...) há de ser recebida, hoje, no sentido de qualquer bem, corpóreo ou incorpóreo, inclusive moeda, papel-moeda, títulos de crédito, créditos documentados, propriedade intelectual e propriedade industrial, que possa ser alienado como elementos de circulação comercial, portanto desde a produção" (F. C. PONTES DE MIRANDA. Tratado de direito privado. Rio de Janeiro: Borsói, 1956, p.381, v.15).

$40 \quad$ V. $\$ 3^{\circ}$, tít. 6, infra.

41 "Com elas [as garantias institucionais], o que se tem por fito é a proteção a determinadas instituições estatais (...). A propriedade, por exemplo, (...) [garantida pela Constituição], é o direito de propriedade tal como a lei brasileira o organiza (...). O Brasil mesmo pode mudar de concepção, de modo que será isso o que se garante - a permanência institucional, a despeito da mudança de regras jurídicas” (F. C. PONTES DE MIRANDA. Comentários à Constituição de 1967. São Paulo: Revista dos Tribunais, 1967, p.633-4, v.4).

42 Cf. C. ARMBRÜSTER. Münchener Kommentar zum Bürgerlichen Gesetzbuch: Allgemeiner Teil §§ 1240. 5. ed. München: C. H. Beck, 2006, p.1633, v.1.1; E. WAGNER. Rechtsgeschäftliche Unübertragbarkeit und $\S 137$ S. 1 BGB. In: Archiv für die civilistische Praxis 194, 1994, p.468. Cf. tb. F. C. PONTES DE MIRANDA: "A regra é a transferibilidade [sic] dos direitos: os direitos, salvo exceção legal, são transferíveis [sic]” (Tratado de direito privado. Rio de Janeiro: Borsoi, 1955, p.332, v.5, sem grifos no original).

43 W. FLUME. Allgemeiner Teil des bürgerlichen Rechts: Das Rechtsgeschäft. 3. ed. Berlin: Springer, 1979, p. 144; C. W. CANARIS. Die Rechtsfolgen rechtsgeschäftlicher Abtretungsverbote. In: U. HUBER, E. JAYME (hrsg). Festschrift für Rolf Serick zum 70. Geburtstag. Heidelberg: Recht und Wirtschaft, 1992, p.17; B. DEPPING, F. NIKOLAUS. Das rechtsgeschäftliche Abtretungsverbot auf dem Prüfstand ökonomischer Analyse des Rechts. In: Der Betrieb, 1994, p.1200; E. WAGNER. Vertragliche Abtretungsverbot im System zivilrechtlicher Verfügungshindernisse. Tübingen: Mohr, 1994, p.17-38; Absolutwirkung vertraglicher Abtretungsverbot gleich absolute Unwirksamkeit verbotswidriger Abtretung? In: Juristenzeitung, 1994, p.227-33; W. HADDING. Vertraglicher Abtretungsausschluss Überlegungen de lege lata und de lege ferenda. In: Zeitschrift für Wirtschaft und Bankrecht, 1988, p.9-15; W. MUMMENHOFF. Vertragliches Abtretungsverbot und Sicherungszession im deutschen, österreichischen und us-amerikanischen Recht. In: Juristenzeitung, 1979, p.427. 
positivamente sua eficácia ${ }^{44}$. Assim, estipulações jurídico-negociais, absolutas ou relativas, que se manifestem como restrições ao exercício do poder de dispor sobre posições jurídicas subjetivas patrimoniais em favor do alienante ou do adquirente a despeito dos adquirentes subseqüentes, são ineficazes em relação a esses últimos.

Já positivamente, o numerus clausus dos contratos de disposição se identifica pelo reconhecimento da autonomia dos titulares, cujo exercício, nessa matéria, manifestase igual e paradoxalmente em heteronomia privada. Em outras palavras, esse regime jurídico não apenas reconhece a possibilidade de autodeterminação dos titulares de posições jurídicas subjetivas patrimoniais disponíveis, mas legitima, sobretudo, uma zona excepcional de exercício de heteronomia privada. O poder incrível de submeter terceiros, sem precisar capturar sua declaração jurídico-negocial, é a satisfação daquela mencionada exigência de tutela da circulação econômica, a qual não subsiste apenas com efeitos obrigacionais. Outro paradoxo, pois o tráfico livre repudiaria, em princípio, vínculos jurídicos estabelecidos por quem não toma parte dos negócios jurídicos dos quais eles se irradiam. O numerus clausus, nessa perspectiva positiva, reduz à lei a competência para resolver, central e uniformemente, esses paradoxos.

A formulação de um regime de numerus clausus dos contratos de disposição, nesses termos gerais, é fruto de um recente desenvolvimento histórico, que encontra sua maior expressão naquele texto que vem tratado por L. ENNECCERUS e H. C. NIPPERDEY ${ }^{45}$ como uma "norma jurídica fundamental", o $§ 137$ BGB: "Proibição jurídico-negocial de disposição: O poder de dispor sobre um direito disponível não pode ser suprimido ou restringido mediante negócio jurídico. A eficácia de um débito de não dispor de um tal direito não é afetada por este enunciado". Esse texto normativo, perfeitamente adequado ao direito positivo ${ }^{46}$, guarda com o numerus clausus dos direitos

44 R. LIEBS. Die unbeschränkbare Verfügungsbefugnis. In: Archiv für die civilistische Praxis 175, 1975, p.25.

45 Allgemeiner Teil des bürgerlichen Rechts. 15. ed. Tübingen: J. C. B. Mohr, 1960, p.891-2, v.2; cf. tb. F. BAUR. Enneccerus-Nipperdey: Allgemeiner Teil des bürgerlichen Rechts. In: Juristenzeitung, 1961, p.335.

46 "O princípio da irrestringibilidade do poder de disposição existe em todo [sic] sistema jurídico. Se o direito, pretensão, ação ou exceção é suscetível de ser transferido [sic], o poder de dispor é incólume à restrição pelos particulares" (F. C. PONTES DE MIRANDA. Tratado de direito privado. Rio de Janeiro: Borsoi, 1955, p.326, 328-30, v.5, grifos no original). 
reais, para usar as palavras de C. BERGER ${ }^{47}$, um "paralelo evidente"; e, nem por isso, até hoje evidenciado ${ }^{48}$.

Esse "paralelo" consiste, na verdade, em uma sobreposição das funções do regime de numerus clausus dos contratos de disposição - chamado, freqüentemente, regime de proibição das restrições jurídico-negociais ao poder de dispor $^{49}$ - àquelas do regime de numerus clausus dos direitos reais. Ambos buscam controlar aquele fenômeno de fragmentação descentralizada da titularidade, que vem representada, acertadamente, pela fragmentação descentralizada do poder de dispor ${ }^{50}$, o que, como advertido, deve ter com uma reserva de lei no direito positivo. Só que o primeiro refere-se à titularidade, que nada mais é que um modo de propriedade, em um sentido amplíssimo; enquanto o segundo refere-se à propriedade, que nada mais é que um modo de titularidade, circunscrita à matéria dos direitos subjetivos reais ${ }^{51-52}$. Pressupostos a ambos, os contratos que têm por objeto a alteração - e virtualmente a fragmentação - da titularidade das posições jurídicas

47 Rechtsgeschäftliche Verfügungsbeschränkungen. Tübingen: Mohr Siebeck, 1998, p.79.

48 Sobre o § 137 BGB ser o "fundamento" do numerus clausus dos direitos reais, cf. J. VON STAUDINGER, J. KOHLER. J. von Staudingers Kommentar zum Bürgerlichen Gesetzbuch mit Einführungsgesetz und Nebengesetzen: Allgemeiner Teil $\$ \$ 134-163$. Berlin: Sellier-de Gruyter, 2003, p.190, v.4; C. W. CANARIS. Die Verdinglichung obligatorischer Rechte. In: H. H. JAKOBS et alii (hrsg.). Festschrift für Werner Flume zum 70. Geburtstag. Köln: Otto Schmidt, 1978, p. 419-21, v. 1; W. WIEGAND. Numerus clausus der dinglichen Rechte: Zur Entstehung und Bedeutung eines zentralen zivilrechtlichen Dogmas. In: Rechtshistorische Reihe 60, 1987, p.635; H. HATTENHAUER. Über vereintes und entzweites Eigentum. In: J. F. BAUR. Das Eigentum. Göttingen: Vandenhoeck und Ruprecht, 1989, p. 91.

Sobre o § 137 BGB ser uma "segurança", uma "confirmação" ou um "tônico" do numerus clausus dos direitos reais, cf. R. LIEBS. Die unbeschränkbare Verfügungsbefugnis. In: Archiv für die civilistische Praxis 175, 1975, p.26, 34; C. ARMBRÜSTER. Münchener Kommentar zum Bürgerlichen Gesetzbuch: Allgemeiner Teil $\S$ 1-240. 5. ed. München: C. H. Beck, 2006, p.1633, v.1.1; P. SEIFERT. Verfügungsfreiheit und rechtsgeschäftliches Veräußerungsverbot. Frankfurt am Main: Rechtswissenschaftliche Fakultät, 1966, p.91; O. PALANDT et alii. Bürgerliches Gesetzbuch. 67. ed. München: C. H. Beck, 2008, p. 126. O texto mais recente sobre o tema é encontrado na monografia de J. T. FÜLLER, onde há capítulo específico sobre "o significado do $\S 137$ para a tipicidade vinculativa dos direitos subjetivos reais" (Eigenständiges Sachenrecht?. Tübingen: Mohr Siebeck, 2006, p. 38492).

Outras relações sincrônicas são encontradas em M. WIESMANN. Zur Tragweite des $\S 137$ BGB. Münster: Westfälischen Wilhelms-Universität, 1991, p.33-5; W. DÄUBLER. Rechtsgeschäftlicher Ausschlu $\beta$ der Veräußerlichkeit von Rechten? In: Neue juristische Wochenschrift 21.1, 1968, p.1120; G. FURTNER. Die rechtsgeschäftliche Verfügungsbeschränkung und ihre Sicherung. In: Neue juristische Wochenschrift 19.1, 1966, p.185; B. GROßFELD, H. G. GERSCH. Zeitliche Grenzen von privaten Schuldverträgen. In: Juristenzeitung 43, 1988, p.944; W. TIMM. Außenwirkungen vertraglicher Verfügungsverbote? In: Juristenzeitung 44.1, 1989, p.18; R. WANK. Mißbrauch der Treuhandstellung und der Vertretungsmacht. In: Juristische Schulung, 1979, p.402-3.

49 Cf. C. BERGER. Rechtsgeschäftliche Verfügungsbeschränkungen. Tübingen: Mohr Siebeck, 1998, p.15 .

50 Cf. H. HATTENHAUER. Die Entdeckung der Verfügungsmacht: Studien zur Geschichte der Grundstücksverfügung im deutschen Recht des Mittelalters. Hamburg: Joachim Heitmann, 1969, p.141.

$51 \quad$ V. $\$ \S 3^{\circ}$, tít. $6,4^{\circ}$, infra.

52 Cf. I. TOSI. Acte translatif et titularité des droits. Paris: LGDJ, 2006, p.36-8. 
subjetivas patrimoniais disponíveis e, por isso, uma álea de heteronomia privada, ou seja, os contratos de disposição: "O limite à criação, por parte dos agentes privados, de direitos reais que não aqueles postos como tais pela lei não se pode, portanto, encontrar - visto que a natureza real de uma relação se reflete, como vimos, exclusivamente na esfera dos terceiros - senão nas normas que regulam a eficácia do negócio com respeito aos terceiros, e, portanto, sobretudo no art. $1.130^{53}$ Codice Civile, o qual, como recordamos, dispõe que, salvos os casos estabelecidos pela lei (entre os quais podem ingressar os direitos reais), as relações derivadas do contrato limitam a sua eficácia às partes contraentes"

Com efeito, elíptica a expressão numerus clausus dos direitos reais. Em um primeiro desenovelo, significa numerus clausus dos negócios jurídicos que criam direitos subjetivos reais. Obviamente, não se criam direitos subjetivos reais apenas por meio de negócios jurídicos ${ }^{56}$. Dentre os chamados “modos de aquisição da propriedade" contam-se fatos jurídicos em sentido estrito (arts. 1.248, 1.272 CC) e atos-fatos jurídicos (arts. 1.238 a 1.244, 1.260 a 1.266, 1.269 a 1.271 CC). Mas afirmar um regime de numerus clausus, já pela própria configuração do suporte fático de tais normas jurídicas, não é, nesses casos, uma necessidade. Dizer que os direitos subjetivos reais são em numerus clausus, quando há apenas suportes fáticos que desconsideram condutas humanas, ou abstraem ou não relevam a vontade dos agentes privados, é nada mais que redundância ${ }^{57}$. Com efeito, a preocupação em afirmar um regime de numerus clausus só aparece quando as situações jurídicas "oponíveis", entre as quais se incluem os direitos subjetivos reais, podem ser criadas por negócios jurídicos.

53 "Os contratos não têm efeito senão entre as partes contratantes: eles não prejudicam os terceiros nem lhes aproveitam, fora nos casos estabelecidos pela lei”; texto correlato ao atual 1.372 Codice Civile: "Eficácia do contrato: O contrato tem força de lei entre as partes. Não pode ser rompido senão por mútuo consenso ou por causas admitidas pela lei. O contrato não produz efeito em relação aos terceiros, senão nos casos previstos pela lei”.

54 M. GIORGIANNI. Contributo alla teoria dei diritti di godimento su cosa altrui. 1940. Ora in: M. GIORGIANNI. Raccolta di scritti: Itinerari giuridici tra pagine classiche e recenti contributi. Padova: CEDAM, 1996, p.152 (sem grifos no original).

55 Diz o art. 1.379 Codice Civile: "Proibição de alienação: a proibição de alienação estabelecida por contrato tem efeito somente entre as partes, e não é válida [sic] se não estiver contida dentro de convenientes limites de tempo e se não responde a um apreciável interesse de uma das partes" (grifouse). Apesar de semelhança gritante para com o § 137 BGB, não se vê na doutrina italiana relação desse texto normativo com o regime de numerus clausus dos direitos reais (cf. G. CIAN, A. TRABUCCHI. Commentario breve al Codice Civile. 7. ed. Padova: CEDAM, 2004, p. 1329-30; M. FRANZONI. Degli effetti del contratto. In: P. SCHLESINGER. Il Codice Civile: Commentario. Milano: Giuffrè, 1999, p. 421, v.2). Não é demais acrescentar, desde logo, o quanto o art. 1.379 Codice Civile é mais gravoso do que § $137 \mathrm{BGB}$, na medida em que limita até mesmo a celebração de contratos meramente obrigacionais cujo objeto consista em proibições de dispor, na espécie, de alienar.

$56 \quad$ V. $\$ \S 3^{\circ}$, títs. 1 e $2,7^{\circ}$, infra.

$57 \quad$ V. $§ 3^{\circ}$, tít. 4 , infra. 
Sobre qual o tipo desses negócios, a filiação ao sistema das relações jurídicas patrimoniais proposto por F. C. SAVIGNY ${ }^{58}$ não deixa dúvidas ${ }^{59}$. Na medida em que a aquisição originária de direitos subjetivos reais é conseqüência da concretização somente de suportes fáticos em que a conduta humana é desconsiderada, ou a vontade humana ou é irrelevante ou é abstraída, mediante negócios jurídicos o direito positivo reconhece apenas a aquisição derivada de direitos subjetivos reais. Ou são transmitidos translativamente, ou são transmitidos constitutivamente. Está-se diante dos negócios jurídicos de disposição. Uma vez que o suporte fático desses negócios jurídicos vêm marcado pelo consentimento jurídico-negocial declarado de agentes privados, trata-se de contratos de disposição ${ }^{60}$. Aliás, não seria demais salientar que as necessidades econômico-sociais de "criação negocial" - isto é, de atribuição patrimonial - de direitos subjetivos reais, precedem à elaboração jurídica da categoria do contrato de disposição. Essa é só a gênese.

As figuras em espécie dos contratos de disposição não são, contudo, facilmente identificadas no direito positivo. Na verdade, o legislador preferiu enumerar a eficácia dos contratos de disposição de direitos subjetivos reais, e não os próprios elementos desse contrato - portanto contrariamente ao que fez no título VI do livro do direito das obrigações, denominado "das várias espécies de contrato", na sua maioria, obrigacionais (arts. 481 a $853 \mathrm{CC}$ ) - por questão de inegável economia legislativa: a disciplina dessa mesma eficácia se fez comum a todos os fatos jurídicos constitutivos de direitos subjetivos reais, independentemente de sua subclasse. Em outras palavras, a regulação das relações jurídicas reais é unitária. Aliás, fez o mesmo nos três primeiros capítulos do título I do livro de direito das obrigações (“das modalidades das obrigações”, arts. 233 a 251), ao tipificar em dar, fazer e não fazer a eficácia seja dos contratos obrigacionais, seja dos atos ilícitos, seja, ainda, de outros fatos jurídicos obrigacionais ${ }^{61}$. É uma disciplina comum das relações jurídicas obrigacionais. Regularam-se unitariamente, pois, tanto as relações jurídicas reais quanto as relações jurídicas obrigacionais, com irrelevância dos fatos jurídicos que as constituem ${ }^{62}$. Diferentemente foi a orientação na elaboração legislativa do direito das sucessões e do direito de família: em ambos, a regulação unitária é dos fatos

System des heutigen römischen Rechts. Berlin: Veit, 1840, p. 374, v.1. V. §§ $3^{\circ}$, tít. 5, $7^{\circ}$, infra.

V. $\S 7^{\circ}$, infra.

Sobre o necessário e redundante numerus clausus dos negócios jurídicos unilaterais, v. § $3^{\circ}$, títs. 4 e 5 , infra.

61 Cf. J. OVERSTAKE. Essai de classification des contrats spéciaux, Paris: LGDJ, 1969, p.22.

62 D. MEDICUS. Schuldrecht: Allgemeiner Teil. 17. ed. München: C. H. Beck, 2006, p.13. 
jurídicos; a morte, no primeiro caso; o casamento (em sentido amplo) e a paternidade, no segundo. Plural é a regulação das relações jurídicas, que são patrimoniais ou extrapatrimoniais. A estrutura do CC segue, assim, o método do sistema das pandectas da ciência alemã do direito comum: chamado partição em cruz do direito privado (Kreuzeinteilung), foi concebido com primazia em 1807 por G. A. HEISE ${ }^{63}$, superando o sistema das instituições, que pautou o ABGB e o próprio Code Civil ${ }^{64}$.

Em número fechado são, por conseguinte, os tipos de contratos que atribuem direitos subjetivos reais ${ }^{65}$, isto é, os contratos de disposição de direitos subjetivos reais. Eis a elipse. E, considerando que a categoria do contrato de disposição regula a transmissão de outras posições jurídicas subjetivas patrimoniais disponíveis, seria razoável que se questionasse em que medida as notas dos contratos de disposição de direitos subjetivos reais são próprias daquela categoria e independentes, portanto, do caráter da posição jurídica subjetiva patrimonial disponível que integra o objeto desses mesmos contratos.

Tratar-se-ia, fundamentalmente, de delinear um denominador comum das transmissões contratuais ${ }^{66}$, identificado, entre outras peculiaridades, certamente pelo regime de numerus clausus. Pois, como se observou, os efeitos que repercutem na esfera jurídica de terceiros, que o regime de numerus clausus busca equilibrar, não são os decorrentes de quaisquer figuras em espécie de posições jurídicas subjetivas patrimoniais disponíveis. Então reticentes em compreender como o direito das coisas, em um sentido mais estrito, não esgota a disciplina das transmissões contratuais, os juristas ligaram um dos efeitos dessas transmissões, definitivamente, a uma característica conceitual das posições jurídicas subjetivas que são previstas e disciplinadas nesse livro, isto é, os direitos subjetivos reais. Então relutantes em debulhar o monólito que é o chamado caráter absoluto dos direitos subjetivos reais, os juristas não perceberam a eficácia que é própria da alteração e da fragmentação da titularidade das posições jurídicas subjetivas patrimoniais

63 Grundriss eines Systems des gemeinen Civilrechts zum Behuf von Pandecten-Volesungen 3. ed. Heidelberg: Mohr und Winter, 1819, p.26 (primeira edição em 1807; segunda, em 1817; consultada apenas a terceira edição).

64 Cf. H. HATTENHAUER. Conceptos fundamentales del derecho civil: Introducción históricodogmática. Trad de G. Hernández. Barcelona: Ariel, 1987, p.65; D. MEDICUS. Schuldrecht: Allgemeiner Teil. 17. ed. München: C. H. Beck, 2006, p.13.

65 Cf. M. COSTANZA. Il contratto atipico. Milano: Giuffrè, 1981, p.169.

66 Cf. R. LIEBS. Die unbeschränkbare Verfügungsbefugnis. In: Archiv für die civilistische Praxis 175, 1975 , p.33-40. 
disponíveis - e, nesse caso, do poder de dispor sobre essas mesmas posições - decantandoas das características de cada subclasse dessas mesmas posições.

Confinaram, assim, o regime de numerus clausus ao seu berçário: os direitos subjetivos reais são, historicamente, as situações clássicas de fragmentação da titularidade - em espécie, a propriedade ${ }^{67}$. O usufrutuário é imune ao exercício do poder de dispor por parte do nu-proprietário. Em outras palavras, há uma restrição jurídico-negocial ao poder de dispor do nu-proprietário. Ele não dispõe da mesma maneira que o proprietário; esse último dispõe adversus omnes. Quem quer que seja o adquirente da propriedade anteriormente transmitida a título de usufruto não tem poder de dispor (posição de ausência de poder) em face do usufrutuário. Ademais, os direitos subjetivos do usufrutuário não são constringíveis por débitos inadimplidos do nu-proprietário. O mesmo se passa com o superficiário, o usuário, o habitante, o credor anticrético, o credor pignoratício, o credor hipotecário e o titular de direito real de aquisição, seja decorrente de contrato de compromisso de compra e venda, seja decorrente de condição resolutiva inexa à transmissão da propriedade ${ }^{68}$. Com efeito, os direitos subjetivos reais limitados fragmentam a propriedade, em espécie, o poder de dispor. Como técnicas jurídicas de assenhoreamento de um bem econômico até hoje essencial para o capitalismo - as coisas imóveis-bens materiais - a concepção de que sua criação deveria ser reserva de lei, jamais competência dos contratantes, resultou na elaboração do regime de numerus clausus dos direitos reais. Esquema genial de juristas extremamente sensíveis a demandas muito concretas do subsistema econômico, invariavelmente chamuscadas por especulações teóricas de altíssimo nível de abstração ${ }^{69}$, sedimentou-se a tal ponto de seus potenciais para a elaboração jurídica serem, até hoje, negligenciados pelo pensamento jurídico. Como observa W. WIEGAND, o numerus clausus dos direitos reais é tratado como um fundamento axiomático do ordenamento jurídico, "um dogma tão profundamente enraizado na consciência dos juristas que vem afirmado com grande naturalidade",70.

$67 \quad$ V. $\$ 4^{\circ}$, infra.

68 V. $\$ 11^{\circ}$, tít. 22, infra.

69 Cf. W. WIEGAND. Zur theoretischen Begründung der Bodenmobilisierung in der Rechtswissenschaft: Der abstrakte Eigentumsbegriff. In: H. COING, W. WILHELM. Wissenschaft und Kodifikation des Privatrechts im 19. Jahrhundert: Die rechtliche und wirtschaftliche Entwicklung des Grundeigentums und Grundkredits. Frankfurt am Main: Vittorio Klostermann, 1976, p.153-5, v.3.

$70 \quad$ Numerus clausus der dinglichen Rechte: Zur Entstehung und Bedeutung eines zentralen zivilrechtlichen Dogmas. In: Rechtshistorische Reihe 60, 1987, p.623. 
Mesmo no direito alemão, que conta com o poderoso suporte fático descrito pelo $§ 137 \mathrm{BGB}$, esses enviesamentos nem sempre são evitados. Tropeçam os autores com as idéias que parecem, do ponto de vista legal, suficientemente claras. Por exemplo, para W. FLUME, a diferença fundamental entre o direito das obrigações e o direito das coisas está em que, na medida em que esse último trata da atribuição jurídica de bens, o tráfico necessita da uniformidade do "status da atribuição"; mas completa o autor: "também no direito das obrigações o princípio da autonomia contratual, no sentido de uma liberdade de configuração de conteúdo, não se aplica quando se trata da atribuição jurídica de créditos e dívidas já existentes" ${ }^{\prime 71}$. Poderia ter enunciado imediatamente, então, que, do ponto de vista da disciplina da atribuição patrimonial das posições jurídicas subjetivas preexistentes, não há diferença entre o direito das obrigações e o direito das coisas. Como, aliás, o próprio autor vem, posteriormente, enunciar com todas as palavras: "Os tipos de possíveis negócios de disposição estão fixados pelo ordenamento jurídico. Existe um numerus clausus de negócios jurídicos de disposição"72.

No mesmo sentido, a tentativa de diferenciação proposta por C. BERGER: “enquanto o princípio do numerus clausus [dos direitos reais] protege o adquirente ao impedir gravames atípicos e ao providenciar, com isso, direitos sempre uniformes, o $§ 137$ S. 1 BGB assegura a incindível conexão entre direito e poder de dispor e, com isso, a aquisição propriamente. A tipicidade vinculativa [numerus clausus] garante o conteúdo dos direitos adquiridos; o $\S 137$ S. 1 BGB a aquisição, como tal, do direito"73. Entretanto, como reconhece o mesmo autor, “(...) as intersecções são possíveis. Teoricamente é sustentável que uma restrição à disposição determine o conteúdo do direito adquirido, já que concerne a uma alienação subseqüente. Com a tipicidade vinculativa, pode-se fundamentar que uma proibição obrigacional à disposição não pode ser 'realizada' de modo a submeter à proibição de disposição (também) o adquirente de um direito. Em síntese, é certo que uma restrição à disposição não pode prosseguir também como impedimento real de eficácia, isto é, de forma que a sucessiva disposição do adquirente estivesse vinculada a uma confirmabilidade. Isso pode ser fundamentado tanto com o $§ 137$ S. 1 BGB quanto com o princípio do numerus clausus, pois um direito de terceiro à

71 Allgemeiner Teil des bürgerlichen Rechts: Das Rechtsgeschäft. 3. ed. Berlin: Springer, 1979, p.15; no mesmo sentido, H. P. WESTERMANN. Vertragsfreiheit und Typengesetzlichkeit im Recht der Personengesellschaften. Berlin: Springer, 1970, p.30.

72 W. FLUME. Allgemeiner Teil des bürgerlichen Rechts: Das Rechtsgeschäft. 3. ed. Berlin: Springer, 1979, p. 144.

73 Rechtsgeschäftliche Verfügungsbeschränkungen. Tübingen: Mohr Siebeck, 1998, p.79. 
alienação de co-determiná-la forma um atípico direito de configuração" ${ }^{\text {"74 }}$. E, de novo: "porque a reatribuição negocial da senhoria sobre as coisas resulta da transmissão da propriedade, é assegurado que o alienante perde todo o poder de agir e de proibir em respeito à coisa; a transferência resolve plenamente a propriedade para o até então proprietário. O princípio da perda do direito mediante transmissão do direito não se submete às modificações autônomo-privadas. $\mathrm{O}$ alienante não pode conservar nenhum direito de proibição de caráter de propriedade; o adquirente está, em todo caso, submetido aos vínculos obrigacionais de uso e disposição. Isso resulta da tipicidade vinculativa e do $\S 137 B G B^{\text {",75 }}$. Por fim, "se é conferido espaço à vontade das partes contra o círculo de direitos reais tipificados, isso fundamentalmente não pode ser excluído por restrições jurídico-negociais à disposição" ${ }^{, 76}$.

Ora, não é o impedimento de criação de direitos subjetivos reais, representada pela "modificação do conteúdo da propriedade", que caracteriza o regime de numerus clausus, mas sim o impedimento de fragmentação descentralizada da titularidade, rectius, do poder de dispor, o que é historicamente ligado à disposição constitutiva da propriedade. A necessidade de conformar a autonomia nesses contratos leva a um regime de numerus clausus dos contratos de disposição, seja de posições jurídicas subjetivas reais, seja de posições jurídicas subjetivas obrigacionais.

Nessa letargia, não apenas se deixa de superar do ponto de vista lógico-formal o represamento do regime de numerus clausus dos direitos reais. Em ordenamentos jurídicos que, como o brasileiro, não apresentam a norma jurídica escrita prevista no $§ 137$ BGB, deixa-se, essencialmente, de organizar em numerus clausus, do ponto de vista teleológico, as transmissões contratuais. Todas elas põem sempre o risco da fragmentação da titularidade e, por consequiência, o sério comprometimento dos princípios da capacidade de adquirir e da res in commercium. Quer dizer, os problemas que o numerus clausus dos direitos reais busca solucionar não são exclusivos das transmissões contratuais de direitos subjetivos reais, e as soluções que esse mesmo regime jurídico apresenta são legal e sistematicamente adequadas para todas e quaisquer transmissões contratuais. O jurista é convidado, assim, a atualizar as técnicas jurídicas presentes na legislação, textualmente

\footnotetext{
Rechtsgeschäftliche Verfügungsbeschränkungen. Tübingen: Mohr Siebeck, 1998, p.79-80, n.15.

Rechtsgeschäftliche Verfügungsbeschränkungen. Tübingen: Mohr Siebeck, 1998, p.81 (grifou-se).

Rechtsgeschäftliche Verfügungsbeschränkungen. Tübingen: Mohr Siebeck, 1998, p.89.
} 
presas a modelos de assenhoreamento dos bens econômicos que não são mais os únicos utilizados pelos agentes privados. Ao mesmo tempo, não pode prescindir do sistema préestabelecido.

Em outras palavras, o numerus clausus dos direitos reais - ou, menos impropriamente, regime de numerus clausus dos contratos de disposição de direitos reais mais não é que o antecedente histórico de um regime jurídico hoje muito mais amplo, que concerne a todos os contratos de disposição. Marca de uma circulação econômica em que a transmissão contratual não apenas das posições jurídicas subjetivas reais, mas também daquelas obrigacionais - tais como os créditos, as posições contratuais e as participações societárias - é decisiva para as estruturas do subsistema econômico. Nota desse regime é uma conformação peculiar da autonomia contratual no campo das disposições de posições jurídicas subjetivas patrimoniais privadas - não apenas aquelas reais. Essa relação - que desemboca em um regime da autonomia privada nas transmissões contratuais, a ser historicamente construído (Capítulo 2), teoricamente elaborado (Capítulo 3) e empiricamente provado (Capítulo 4) - é o tema desta tese.

\section{CONCLUSÃO}

Em um ordenamento jurídico que, como o brasileiro, promove a autonomia contratual, é virtualmente infinito o número de "gravames" que podem ser criados pelos contratantes. Invariavelmente, esses últimos desejam extrapolar os limites ético-jurídicos da contratualidade: o primeiro accipiens deseja que o segundo submeta-se aos seus interesses econômico-sociais, de modo que esse último esteja impedido de excluir o primeiro do exercício do direito subjetivo patrimonial; o segundo accipiens deseja, por sua vez, excluir o primeiro do exercício do direito subjetivo patrimonial que acredita ter adquirido, com prioridade, do tradens titular. Ora, em uma operação de "transmissão" de uma posição jurídica subjetiva patrimonial, a respeito da qual haja um pacto entre o tradens-titular e o primeiro accipiens, e esse pacto não se enquadre em um dos tipos de gravames reconhecidos pelo ordenamento jurídico, quatro são as soluções técnicas possíveis: 
1. ou se sustenta que o terceiro-adquirente, quer dizer, o segundo accipiens pode simplesmente desconsiderar o "gravame", na medida em que ele é atípico, excluindo o primeiro accipiens do exercício do direito subjetivo patrimonial do qual é, tão-somente, credor. Basta a esse último a pretensão indenizatória por incumprimento contratual (ato ilícito relativo; art. 389 CC). Aplica-se, nesses termos, o regime de numerus clausus, em toda a sua inteireza;

2. ou se sustenta que o terceiro-adquirente, o segundo accipiens, conquanto tenha adquirido eficazmente o direito subjetivo patrimonial, pode ser responsável extracontratualmente (CC, art. 186), porque conhecia ou deveria conhecer o pacto. Preserva-se, de qualquer maneira, a responsabilidade contratual do tradens titular (CC, art. 389);

3. ou se sustenta que o terceiro-adquirente, o segundo accipiens, adquiriu também uma posição jurídica subjetiva obrigacional, em virtude de sub-rogação, caso em que se destacam as exceções materiais propter rem, decorrentes da mediatização da posse e da disciplina da cessão da pretensão à entrega (tradição ficta);

4. ou se sustenta que o terceiro-adquirente, segundo accipiens, tem encoberta alguma, ou algumas, ou todas as posições jurídicas subjetivas patrimoniais adquiridas, em razão de deveres de proteção do patrimônio alheio. Trata-se de eficácia não de um antecedente contrato de disposição - a hipótese pressupõe exatamente a inexistência desse último - mas sim de uma concretização do princípio da boa-fé objetiva, especificamente da figura do exercício inadmissível de posição jurídica, com fundamento legal no art. 187 do $\mathrm{CC}$.

O modelo do direito positivo é o de número 1, por princípio. Porque ele se preocupa, fundamentalmente, com a segurança da aquisição: como aqueles pactos não têm uma tipicidade legal, não existem parâmetros legais para investigar o conteúdo do negócio, ainda mais considerando que o adquirente dele não participou. Nesses termos, o regime de numerus clausus dos contratos de disposição tem como função assegurar o adquirente de uma posição jurídica subjetiva patrimonial do status de atribuição dessa última, quer dizer, dos gravames que possam impedi-lo de adquirir uma posição jurídica subjetiva patrimonial e exercer o conteúdo típico dessa última. Privilegia-se um mecanismo de verificação $a$ priori do status da atribuição, em consonância com os valores do direito codificado. E se 
lhe dá a possibilidade de desprezar os interesses econômico-sociais do mero credor (primeiro accipiens).

Em síntese, o regime jurídico convencionalmente designado pela expressão “numerus clausus dos direitos reais" tem um adequado enquadramento dogmático mediante a construção de um regime jurídico de numerus clausus dos contratos de disposição. Na medida em que as figuras jurídicas dos contratos de disposição têm, por objeto, a alteração da titularidade das posições jurídicas subjetivas patrimoniais, mais especificamente a regulação autônomo-privada do poder de dispor sobre essas últimas, conferem a esse ato de transmissão a eficácia real: por meio da regra da prioridade e da conseqüente imunidade contra disposição manifesta-se claramente um fenômeno de heteronomia privada. O adquirente, em sentido estrito, não apenas está relativamente imune aos contratos, obrigacionais e de disposição, subseqüentes que se refiram à sua posição jurídica subjetiva patrimonial, como também pode desconsiderar a eficácia dos contratos obrigacionais precedentes que se refiram à posição jurídica subjetiva patrimonial adquirida. Da mesma maneira, está imune às execuções judiciais, individuais ou concursais, que recaiam sobre sua posição jurídica subjetiva patrimonial: pode opor embargos de terceiro contra penhoras e é beneficiado por "preferências" nos concursos.

Esse problema se acentua em máximo grau, quando se trata da disposição contratual constitutiva, pois a multiplicação de precedências e imunidades contra disposição a respeito de um mesmo direito subjetivo patrimonial delineia nitidamente a modificação autônomo-privada não apenas do poder de dispor sobre esse direito, mas também do poder de adquiri-lo. A modificação dos fatores de disponibilidade de um mesmo direito subjetivo patrimonial, nos seus elementos subjetivos (quem pode e quem não pode dispor), objetivos (sobre o que não se pode dispor) e modais (de que maneira se pode dispor), implica definições jurídico-negociais de falta de legitimação para dispor; por reflexo, impõe, outrossim, modificação dos fatores de adquiribilidade de um mesmo direito subjetivo patrimonial e definições jurídico-negociais de falta de legitimação para adquirir. O fenômeno fica elucidado por meio da dogmática dos contratos de disposição, na medida em que ela explica como os suportes fáticos, compósitos, desses últimos equacionam poder de dispor e aquisição (derivada) de uma posição jurídica subjetiva patrimonial logicamente preexistente. Disposição contratual e aquisição contratual derivada são um só e mesmo fenômeno, que é, simultaneamente, resultado e modificação do poder de dispor. 
O regime de numerus clausus reduz essa heteronomia a quem tem legitimidade política para heterodeterminar: a lei. Realiza-o de um modo tecnicamente sofisticado, porque reconhece mais de um tipo de disposição contratual, especialmente mais de um tipo de disposição contratual constitutiva; porque promove a autonomia nos contratos obrigacionais, ainda que referentes aos poderes dos titulares, entre eles, dos proprietários; e porque satisfaz a necessidade econômico-social de heteronomia privada - politicamente legitimada, porque agora amparada na lei - conferindo estabilidade a determinadas relações de intercâmbio de bens econômicos, em face de terceiros-adquirentes.

Esse caráter genérico de oponibilidade de interesses econômico-sociais aos terceiros-adquirentes é apresentado por outras técnicas jurídicas, que não se organizam, contudo, mediante a regra da prioridade e a imunidade contra disposição. Nada obstante, podem implicar encobrimentos, por sub-rogação legal ou por deveres de proteção do patrimônio alheio, a posições jurídicas subjetivas patrimoniais adquiridas, cujo exercício seria, inicialmente, tutelado pela técnica do contrato de disposição. A presença daquelas outras técnicas de oponibilidade de interesses econômico-sociais aos terceiros-adquirentes, muito especialmente no segundo caso, que decorre da concretização a boa-fé objetiva, não derroga o regime de numerus clausus. $\mathrm{O}$ direito patrimonial privado organiza-se por meio de diversos princípios cuja harmonização compete ao pensamento jurídico. Ao propor essa harmonização, descobre-se, essencialmente, que o regime de numerus clausus continua sendo a regulação principal do tráfico jurídico, por satisfazer as exigências de segurança postas por esse último.

A falta de consciência ético-jurídica se pronuncia, nessa matéria, tanto pela incompreensão das funções desempenhadas pelo numerus clausus quanto pelo emprego de categorias tradicionais para a explicação de fenômenos novos, como se se sustenta um direito subjetivo real, ou melhor, um contrato de disposição, onde, logicamente, só há obrigações. A razão humana, em vez de se realizar integralmente, aliena-se a soluções de acaso, num mecânico ou impotente acatamento perante à prolatada novidade ou à conveniência da tradição ${ }^{77}$. A dogmática jurídica, ao contrário, contribui para que, libertando-se dos criptoargumentos, a responsabilidade de uma decisão seja plenamente

77 C. A. MOTA PINTO. Cessão de contrato. São Paulo: Saraiva, 1985, p.8. 
assumida, em vez de render-se à invocação de enunciados estrambólicos ou de princípios aceitos por força de uma atitude de inércia. Ela permite, também, que a justificação das decisões ditadas pela justiça ou outros valores não recorra a um processo preconceituoso de demolição ou à recepção de conceitos e princípios já assentados. Rompe, por fim, a tendência espúria de legitimar uma solução jurídica por encobri-la no manto seja da pura novidade, seja da categoria consagrada.

Ora, o direito é, fundamentalmente, uma manifestação do espírito humano, algo que é reconhecido e intencionado na consciência do homem ${ }^{78}$. Entre o direito e o discurso sobre o direito, há um campo infinito e contingente, animado pelos valores e pela história. Tarefa do pensamento jurídico é oferecer as pautas de elaboração do segundo, sem desprezar o primeiro; e os mecanismos de desenvolvimento do primeiro, mediante as conquistas do segundo. Entre a realidade e a opinião, há o espírito humano, a consciência ético-jurídica do homem. Macula-a a adesão tanto a raciocínios puramente lógicodiscursivos e verbalistas quanto à "natureza das coisas". Pois tira-lhe o próprio assento de consciência: o direito perde seu valor como idéia humana; vira pura conveniência, irracionalidade, ausência de qualquer avaliação; rouba do homem seu poder de construção pela história, baseada em um ato de pensamento, com que a humanidade constitui uma vida que lhe pertence, orientada e baseada sobre a sua autonomia ${ }^{79}$; abre-se, enfim, à captura e à domesticação pelo poder e pela violência. 'Um pensamento jurídico 'puro', isto é, expurgado daquilo que é estranho à sua natureza problemática e valorativa e das suas funções e finalidades práticas" ${ }^{80}$, pressupõe necessariamente a consciência dos interesses e dos valores sociais, atuais ou, como os tutelados pelo regime de numerus clausus, ainda muito atuais.

C. A. MOTA PINTO. Cessão de contrato. São Paulo: Saraiva, 1985, p.6.

C. A. MOTA PINTO. Cessão de contrato. São Paulo: Saraiva, 1985, p.8.

C. A. MOTA PINTO. Cessão de contrato. São Paulo: Saraiva, 1985, p.7. 


\section{BIBLIOGRAFIA}

ABERKANE, Hassen. Contribution à l'étude de la distinction des droits de créance et des droits réels. Paris: LGDJ, 1957.

ACHILLES, Alexander. Protokolle der Komission für die zweite Lesung des Entwurfs eines Bürgerlichen Gesetzbuchs: Sachenrecht. Berlin: Guttentag, 1899, v.3.

ACKERMAN, Bruce A. Economic foundations of property law. [S.1.]: Aspen, 1975.

AGAPITO DA VEIGA, Dídimo. Direito hypothecario. Rio de Janeiro: Lammert \& C., 1899.

AKKERMANS, Bram. The Principle of Numerus Clausus in European Property Law. Antwerpen: Intersentia, 2008.

ALENCAR, José de. A propriedade. Rio de Janeiro: B. L. Garnier, 1883.

ALLARA, Mario. Le nozione fondamentali del diritto civile. 5. ed. Torino: Giappichelli, 1958, v.1.

ALLONSO Y CALERA, Maria del Carmen G. Estructura y función del tipo contractual. Barcelona: Bosch, 1979.

ANTUNES VARELA, João de Matos. Direito das obrigações. Rio de Janeiro: Forense, $1978,2 \mathrm{v}$.

ARMBRÜSTER, Christian. Münchener Kommentar zum Bürgerlichen Gesetzbuch: Allgemeiner Teil §§ 1-240. 5. ed. München: C. H. Beck, 2006, v.1.1.

ARNAUD, André-Jean. Les origines doctrinales du Code Civil français. Paris: LGDJ, 1969.

ARNDTS, Ludwig. Lehrbuch der Pandekten. 9 ed. Stuttgart: Cotta, 1877.

ARRUDA ALVIM NETO, José Manoel de Arruda. Confronto entre situação de direito real e de direito obrigacional: Prevalência da primeira, prévia e legitimidade constituída; salvo lei expressa em sentido contrario. In: Revista de Direito Privado 1, 2000, p.93-136.

ASCARELLI, Tullio. Teoria geral dos títulos de crédito. 2. ed. Trad. Nicolau Nazo. São Paulo: Saraiva, 1969.

ATIYAH, Patrick Selim. The Rise and Fall of Freedom of Contract. Oxford: Oxford University, 1979. 
AUBRY, Charles; RAU, Charles. Cours de droit civil français d'après la methode de Zachariae. 6. ed. Paris: Marchal et Billard, 1935, v.2.

AVELÃS NUNES, Antonio José. O direito de exclusão de sócios nas sociedades comerciais. Coimbra, 1968.

AZEVEDO, Philadelpho. Destinação do imóvel. 2. ed. São Paulo: Max Limonad, 1957.

BANKE, Bernd Erich. Das Anwartschaftsrecht aus Eigentumsvorbehalt in der Einzelzwangsvollstreckung. Berlin: Duncker und Humblot, 1991.

BAPTISTA DA SILVA, Ovídio. Comentários ao Código de Processo Civil: Do Processo Cautelar. 2. ed. Porto Alegre: Letras Jurídicas, 1986.

BARASSI, Lodovico. Proprietà e comproprietà. Milão: Giuffrè, 1951.

BARBOSA LIMA SOB., Alexandre José. As transformações da compra e venda. Rio de Janeiro: Borsoi, 19--.

BARCELLONA, Pietro. Diritto privato e società moderna. Napoli: Jovene, 1996.

BARCELlONA, Pietro. Proprietà (tutela costituzionale). In: Digesto delle discipline privatistiche - sezione civile 15, 1998, p.456-468.

BARCELONA, Mario. Proprietà privata e intervento statale: Profili istituzionali della questione agraria. Napoli: Jovene, 1980.

BARNI, Gianluigi. Proprietà (diritto intermedio). In: Novissimo digesto italiano 14, 1967, p.120-125.

BAUDRY-LACANTINERIE, Gabriel; CHAUVEAU, Adolphe M. Traité théorique et pratique de droit civil: Des biens. 3. ed. Paris: Sirey, 1905, v.3.

BAUR, Fritz. Enneccerus-Nipperdey: Allgemeiner Teil des bürgerlichen Rechts. In: Juristenzeitung, 1961, p.334-5.

BAUR, Fritz; BAUR, Jürgen F., STÜRNER, Rolf. Lehrbuch des Sachenrechts. 16. ed. München: C. H. Beck, 1992.

BAUR, Fritz; BAUR, Jürgen F.; STÜRNER, Rolf. Sachenrecht. 17. ed. München: C. H. Beck, 1999.

BEDUSCHI, Carlo. Tipicità e diritto: Contributo allo studio della razionalità giuridica. Padova: CEDAM, 1992.

BEHRENDS, Okko. Die rechtsethischen Grundlagen des Privatrechts. In: BYDLINSKI, Franz; MAYER-MALY, Theo (hrsg.). Die ethischen Grundlagen des Privatrechts. Wien: Springer, 1994, p.1-33. 
BELFIORE, Angelo. Interpretazione e dommatica nella teoria dei diritti reali. Milano: Giuffrè, 1979.

BELLEY, Jean-Guy. Max Weber et la théorie du droit des contrats. In: Droit et société 9, 1988, p.301-24.

BERGER, Christian. Rechtsgeschäftliche Verfügungsbeschränkungen. Tübingen: Mohr Siebeck, 1998.

BERGER, Wolfgang. Eigentumsvorbehalt und Anwartschaftsrecht. Frankfurt am Main: Peter Lang, 1984.

BERNARDES DE MELLO, Marcos. Teoria do fato jurídico: Plano da existência. 10. ed. São Paulo: Saraiva, 2000.

BESSONE, Darcy. Da compra e venda: Promessa e reserva de domínio. 3. ed. São Paulo: Saraiva, 1988.

BESSONE, Darcy. Da posse. São Paulo: Saraiva, 1996.

BESSONE, Darcy. Direitos reais. 2. ed. São Paulo: Saraiva, 1996.

BESSONE, Darcy. Do contrato: Teoria geral. 4 ed. São Paulo: Saraiva, 1997.

BETTI, Emilio. Autonomia privata. In: Novissimo Digesto Italiano 1, 2, 1957, p. 1559-61.

BETTI, Emilio. Der Typenzwang bei den römischen Rechtsgeschäften und die sogenannte Typenfreiheit des heutigen Rechts. In: Festschrift für Leopold Wenger. München: C. H. Beck, 1944, p.249-83, v.1.

BETTI, Emilio. Moderne dogmatische Begriffsbildung in der Rechts- und Kulturgeschichte. In: Studium Generale: Zeitschrift für die Einheit der Wissenschaft im Zusammenhang ihrer Begriffsbildungen und Forschungsmethoden 12, 1959, p.8796.

BETTI, Emilio. Teoria generale del negozio giuridico. Napoli: Edizione Scientifiche Italiane, 1994.

BETTI, Emilio. Teoria generale delle obbligazioni. Milano: Giuffrè, 1953, v.1.

BETTI, Emilio. Teoria generale delle obbligazioni. Milano: Giuffrè, 1953, v.2.

BETTI, Emilio. Teoria generale delle obbligazioni. Milano: Giuffrè, 1954, v.3.

BEVILAQUA, Clovis. Código Civil dos Estados Unidos do Brasil comentado. 10. ed. Rio de Janeiro: Livraria Francisco Alves, 1955, v.3.

BEVILAQUA, Clovis. Direito das coisas. Rio de Janeiro: Freitas Bastos, 1941, v.1. 
BEVILAQUA, Clovis. Direito das obrigações. 4. ed. Rio de Janeiro: Freitas Bastos, 1936.

BEYERLE, Franz. Der dingliche Vertrag. In: Festschrift für Gustav Boehmer. Bonn: Ludwig Röhrscheid, 1954, p.164-76.

BIANCA, Cesare Massimo. Diritto civile: Il contratto. 2. ed. Milano: Giuffrè, 2000, v.3.

BIANCA, Cesare Massimo. Diritto civile: La proprietà. Milano: Giuffrè, 1999, v.6.

BINETTE, Serge. De l'effet relatif de l'enregistrement des droits réels. In: La Revue du notariat 7-8, 1988, p.370-83.

BIONDI, Biondo. Le servitù. In: CICU, Antonio, MESSINEO, Francesco (org.). Trattato di diritto civile e commerciale. Milano: Giuffrè, 1967, v.12.

BIROCCHI, Italo. Saggi sulla formazione storica della categoria generale del contrato. Cagliari: Cuec, 1988.

BLOCH, Marc. La société féodale. Paris: Albin Michel, 1949, 2v.

BOBBIO, Norberto. Locke e o direito natural. Trad. de S. Bath. 2. ed. Brasília: UNB, 1997.

BOCCHINI, Fernando. Limitazioni convenzionali del potere di disposizione. Napoli: Jovene, 1977.

BRANCA, Giuseppe. Servitù prediali. 4. ed. Bologna: Zanichelli, 1967.

BRANDT, Reinhard. Eigentumstheorien von Grotius bis Kant. Stuttgart: Friedrich Frommann, 1974.

BRASIELLO, Ugo. Proprietà (diritto romano). In: Novissimo digesto italiano 14, 1967, p. 111-20.

BRAUDEL, Fernand. Civilisation matérielle, économie et capitalisme XV $V^{e}$-XVIII ${ }^{e}$ siècle: Les jeux de l'échange. Paris: Librairie Armand Colin, 1979.

BRIENZA, Arturo. La tassatività delle ipotesi di trascrizioni: Superamento o conferma di un principio? In: Rivista di diritto civile 5, 1991, p.571-88.

BRINZ, Allois. Lehrbuch der Pandekten. 2. ed. Erlangen: Deichert, 1873, v.1.

BROCHU, François. Pleins feux sur le nouveau registre des droits personnels et reels mobiliers. In: Revue du notariat 2, 1994, p.228-64.

BUCHHOLZ, Stephan. Abstraktionsprinzip und Immobiliarrecht: Zur Geschichte der Auflassung und der Grundschuld. Frankfurt am Main: Vittorio Klostermann, 1978. 
BÜLOW, Peter. Grundfragen der Verfügungsverbote. In: Juristische Schulung, 1994, p.18.

BUFNOIR, Claude. Propriété et contrat: Théorie des modes d'acquisition des droits réels et des sources des obligations. 2. ed. Paris: Rousseau, 1924.

BURDESE. Ancora sulla natura e tipicità dei diritti reali. In: Rivista di diritto civile 2, 1983, p.236-8.

BUSSI, Emilio. La formazione dei dogmi di diritto privato nel diritto comune: Diritti reali e diritti di obbligazione. Padova: CEDAM, 1937.

BYDLINSKI, Franz. Privatautonomie und objektive Grundlagen des verpflichtenden Rechtsgeschäftes. Wien: Springer, 1967.

BYDLINSKI, Franz. System und Prinzipien des Privatrechts. Wien: Springer, 1996.

CANARIS, Claus-Wilhelm. $\S 354$ a. In: CANARIS, Claus-Wilhelm et alii (hrsg.). Handelsgesetzbuch Staub. 4. ed. Berlin: De Gruyter, 2004, v.4.

CANARIS, Claus-Wilhelm. Die Bedeutung der iustitia distributiva im deutschen Vertragsrecht. München: Bayerischen Akademie der Wissenschaften, 1997.

CANARIS, Claus-Wilhelm. Die Rechtsfolgen rechtsgeschäftlicher Abtretungsverbote. In: HUBER, Ulrich; JAYME, Erik (hrsg). Festschrift für Rolf Serick zum 70. Geburtstag. Heidelberg: Recht und Wirtschaft, 1992, p.9-35.

CANARIS, Claus-Wilhelm. Die Verdinglichung obligatorischer Rechte. In: JAKOBS, Horst Heinrich et alii (hrsg.). Festschrift für Werner Flume zum 70. Geburtstag. Köln: Otto Schmidt, 1978, p. 371-427, v.1.

CANARIS, Claus-Wilhelm. Die Vertrauenshaftung im deutschen Privatrecht. München: C. H. Beck, 1971.

CANARIS, Claus-Wilhelm. Schutzgesetze, Verkehrspflichten, Schutzpflichten. In: CANARIS, Claus-Wilhelm, DIEDERICHSEN, Uwe. Festschrift für Karl Larenz zum 80. Geburtstag. München: C. H. Beck, 1983, p.28-110.

CANARIS, Claus-Wilhelm. Pensamento sistemático e conceito de sistema na ciência do direito. Trad. de Menezes Cordeiro. 2. ed. Lisboa: Calouste Gulbenkian, 1996.

CANARIS, Claus-Wilhelm. Verfassungs- und europarechtliche Aspekte der Vertragsfreiheit in der Privatrechtsgesellschaft. In: BADURA, Peter (hrsg.). Festschrift für Peter Lerche zum 65. Geburtstag. München: C. H. Beck, 1993, p.87391. 
CANDIAN, Albina; GAMBARO, Antonio; POZZO, Barbara. Property, propriété, Eigentum: Corso di diritto privato comparato. Padova: CEDAM, 2002.

CANTARELlA, Eva. Proprietà (diritto greco). In: Novissimo digesto italiano 14, 1967, p.99-110.

CAPELLE, Karl-Hermann. Bügerliches Recht: Sachenrecht. Wiesbaden: Gabler, 1964.

CAPITANT, Henri. Introduction a l'étude du droit civil: Notions générales. 4. ed. Paris: A. Pedone, 1921.

CAPOGROSSI COLOGNESI, Luigi. Proprietà in generale: Diritto romano. In: Enciclopedia del diritto 37, 1988, p.160-225.

CAPPELLINI, Paolo. Systema iuris: Genesi del sistema e nascita della "scienza" delle Pandette. Milano: Giuffrè, 1984.

CAPPELLINI, Paolo. Systema iuris: Dal sistema alla teoria generale. Milano: Giuffrè, 1985.

CARBONNIER, Jean. Droit civil: Les biens. Les obligations. Paris: PUF, 2004 v.2.

CARNEIRO MAIA, Paulo. Da retrovenda. São Paulo: Saraiva, 1955.

CARNELUTTI, Francesco. Teoria giuridica della circolazione. Padova: CEDAM, 1933.

CARNEVALI DE CAMACHO, Magaly. Derecho de credito y derechos reales. In: Anuario de la Facultad de Ciencias Jurídicas y Políticas 19, 1995-96, p.13-36.

CAROSSO, Luigi. La delega nel diritto civile: La delega dominica. Torino: Giappichelli, 1980.

CAROSSO, Luigi. La delega nel diritto civile: Delega e destinazione reale. Torino: Giappichelli, 1980.

CAROSSO, Luigi. La delega nel diritto civile: Delega e "stati di proprietà". Torino: Giappichelli, 1981.

CAROSSO, Luigi. La delega nel diritto civile: La delega possessoria. Torino: Giappichelli, 1983.

CARVALHO DE MENDONÇA, Manoel Ignácio. Introdução geral ao direito das cousas: Dos direitos reais. Rio de Janeiro: Jacintho Ribeiro dos Santos, 1915.

CARVALHO, Afrânio de. Registro de imóveis. Rio de Janeiro: Forense, 1982.

CARVALHOSA, Modesto. Acordo de acionistas. São Paulo: Saraiva, 1984. 
CASELLI, Giovanni. Note su servità e tipicità delle obbligazione reali. In: Rivista giuridica dell'edilizia 6, 1989, p.175-87.

CAVALCANTI, José Paulo. Direito civil: Escritos diversos. Rio de Janeiro: Forense, 1983.

CENEVIVA, Walter. Lei dos Registros Públicos comentada. 6. ed. São Paulo: Saraiva, 1988.

CENTRO DI STUDI FILOSOFICI DI GALLARATE - ISTITUTO PER LA COLlABORAZIONE CULTURALE. Proprietà. In: Enciclopedia filosofica 3, 1957, p.1663-1668.

CENTRO DI STUDI FILOSOFICI DI GALLARATE - ISTITUTO PER LA COLlABORAZIONE CULTURALE. Proprio. In: Enciclopedia filosofica 3, 1957, p.1668-1670.

CHATEAUBRIAND FILHO, Hindemburgo. Autonomia privada e tipicidade dos direitos reais. In: Revista dos Tribunais 745, 1997, p.41-47.

CHAZAL, Jean Pascal; VICENTE, Serge. Le transfert de propriété par l'effet des obligations dans le code civil. In: Revue trimestrielle de droit civil 3, 2000, p.477506.

CHIANALE, Angelo. Obbligazione di dare e trasferimento della proprietà. Milano: Giuffrè, 1990.

CIAN, Giorgio; TRABUCCHI, Alberto. Commentario breve al Codice Civile. 7. ed. Padova: CEDAM, 2004.

CLARKE, Alison; KOHLER, Paul. Property Law: Commentary and Materials. Cambridge: Cambridge University, 2005.

COELHO DA ROCHA, Manuel Antonio. Instituições de direito civil. In: TOMASETTI JÚNIOR, Alcides. Clássicos do Direito Brasileiro. São Paulo, Saraiva, 1984, 2 v.

COING, Helmut. Europäisches Privatrecht: Älteres Gemeines Recht (1500 bis 1800). München: C. H. Beck, 1985, v.1.

COING, Helmut. Europäisches Privatrecht: Überblick über die Entwicklung des Privatrechts in den ehemals gemeinrechtlichen Ländern (19. Jahrhundert). München: C. H. Beck, 1989, v.2.

COLORNI, Vittore. Per la storia della pubblicità immobiliare e mobiliare. Milano: Giuffrè, 1962. 
COMMONS, John. Legal Foundations of Capitalism. New Jersey: Augustus M. Kelley, 1974.

COMPARATO, Fábio Konder. Aspectos jurídicos da macro-empresa. São Paulo: Revista dos Tribunais, 1970.

COMPARATO, Fabio Konder. Exclusão de sócio nas sociedades por quotas de responsabilidade limitada. In: Revista de direito mercantil 25, 1977, p.37-49.

COMPARATO, Fabio Konder. Novos ensaios e pareceres de direito empresarial. Rio de Janeiro: Forense, 1981.

COMPARATO, Fabio Konder. O poder de controle na sociedade anônima. São Paulo: Revista dos Tribunais, 1976.

COMPARATO, Fábio Konder. O seguro de crédito: Estudo jurídico. São Paulo: Max Limonad, 1966.

COMPORTI, Marco. Contributo allo studio del diritto reale. Milano: Giuffrè, 1977.

COMPORTI, Marco. Diritti reali in generali. In: CICU, Antonio; MESSINEO, Francesco; MENGONI, Luigi. (org.). Trattato di diritto civile e commerciale. Milano: Giuffrè, 1980, v.8.1.

COOKE, Elizabeth. Modern studies in property law. Londres: Hart, 2003.

COOTER, Robert; ULEN, Thomas. Derecho y economía. Trad. esp. de E. Suárez. México: Fondo de Cultura Económica, 1998.

COSTA, Dilvanir Jose da. O conceito de direito real. In: Revista de informação legislativa 144, 1999, p.71-9.

COSTANZA, Maria. Il contratto atipico. Milano: Giuffrè, 1981.

COTTINO, Gastone. Diritto societario. 5. ed. Padova: Cedam, 2006.

COUTO E SILVA, Clóvis Veríssimo do. A hipoteca no direito comparado. In: FRADERA, Vera Maria Jacob (org.). O direito privado brasileiro na visão de Clóvis do Couto e Silva. Porto Alegre: Livraria do advogado, 1997, p.137-176.

COUTO E SILVA, Clovis Veríssimo do. A obrigação como processo. São Paulo: Bushatsky, 1976.

COUTO E SILVA, Clóvis Veríssimo do. A teoria da causa no direito privado. In: FRADERA, Vera Maria Jacob (org.). O direito privado brasileiro na visão de Clóvis do Couto e Silva. Porto Alegre: Livraria do advogado, 1997, p.59-71. 
COUTO E SILVA, Clóvis Veríssimo do. Negócio jurídico e negócio jurídico de disposição. In: FRADERA, Vera Maria Jacob (org.). O direito privado brasileiro na visão de Clóvis do Couto e Silva. Porto Alegre: Livraria do advogado, 1997, p.73-87.

COUTO E SILVA, Clóvis Veríssimo do. O direito civil brasileiro em perspectiva histórica e visão de futuro. In: Revista Ajuris 40, 1987, p.148-58.

CRISTAS, Assunção; GOUVEIA, Mariana França; NEVES, Vítor Pereira. Transmissão da propriedade e contrato. Coimbra: Almedina, 2001.

CRISTAS, Maria de Assunção. Transmissão contratual do direito de crédito: Do caráter real do direito de crédito. Coimbra: Almedina, 2005.

CROME, Carl. System des deutschen bürgerlichen Rechts. Tübingen: Mohr, 1900, v.1.

CROME, Carl. System des deutschen bürgerlichen Rechts. Tübingen: Mohr, 1905, v.3.

DABIN, Jean. Une nouvelle définition du droit réel. In: Revue trimestrielle de droit civil 60,1962, p.21-44.

DÄUBLER, Wolfgang. Rechtsgeschäftlicher Ausschluß der Veräußerlichkeit von Rechten? In: Neue juristische Wochenschrift 21.1, 1968, p.1117-23.

DE NOVA, Giorgio. Il tipo contrattuale. Padova: CEDAM, 1974.

DEMOLOMBE, Charles. Cours de Code Napoléon: Traité de la distinction des biens. Paris: A. Lahure, 1881, v.9.

DENCK, Johannes. Relativität im Sachenrecht. In: Juristische Schulung 12, 1981, p.861-6.

DEPPING, Bernd; NIKOLAUS, Frank. Das rechtsgeschäftliche Abtretungsverbot auf dem Prüfstand ökonomischer Analyse des Rechts. In: Der Betrieb, 1994, p.1199-203.

DERNBURG, Heinrich. Diritti reali. Trad. de F. Cicala. Roma: Fratelli Bocca, 1907, v.1, 2.

DERZI, Misabel de Abreu Machado. Direito tributário, direito penal e tipo. São Paulo: Revista dos Tribunais, 1988.

DI LAURO, Antonio Procida Mirabelli. La proprietà come rapporto: A proposito dell'interpretazione unitaria e sistematica dell'art. 844 c.c. In: Rassegna di diritto civile 2, 1998, p.347-74.

DI MAJO, Adolfo; FRANCARIO, Lucio. Proprietà e autonomia contrattuale. Milano: Giuffrè, 1990.

DI MAJO, Adolfo; FRANCARIO, Lucio. Proprietà edilizia. In: Enciclopedia del diritto 37, 1968, p.338-368. 
DÍEZ-PICAZO, Luís María; GULLÓN BALLESTEROS, Antonio. Sistema de derecho civil: Derecho de cosas y Derecho Inmobiliario Registral. 7. ed. Madrid: Tecnos, 2005, v.3.

DILCHER, Hermann. Typenfreiheit und inhaltliche Gestaltungsfreiheit bei Verträgen. In: Neue juristische Wochenschrift 1960, p.1040-3.

DOMINGUES DE ANDRADE, Manuel Domingues de. Teoria geral da relação jurídica. Coimbra: Almedina, 1992, v.2.

DORIA, Giovanni. Doppia alienazione immobiliare e teoria dell'effetto reale: Il problema della responsabilità dell'alienante e del secondo acquirente. Milano: Giuffrè, 1994.

DORN, Franz. § 137. Rechtsgeschäftliches Verfügungsverbot. In: SCHMOECKEL, Mathias; RÜCKERT, Joachim; ZIMMERMANN, Reinhard (hrsg.). Historischkritischer Kommentar zum BGB: Allgemeiner Teil §§ 1-240. Tübingen: Mohr Siebeck, 2003, p.692-707.

DÖRNER, Heinrich. Dynamische Relativität: Der Übergang vertraglicher Rechte und Pflichten. München: C. H. Beck, 1985.

DUARTE, Rui Pinto. Tipicidade e atipicidade dos contratos. Coimbra: Almedina, 2000.

DULCKEIT, Gerhard. Die verdinglichung obligatorischer Rechte. Tübingen: MohrSiebeck, 1951.

KRAMER, Ernst. Die „Krise“ des liberalen Vertragsdenkens: Eine Standortbestimmung. München: Fink, 1974.

EDER, Ulrich. Das Pfandrecht am Anwartschaftsrecht des Vorbehaltskäufers. Münster: Juristische Dissertation 22, 1990.

EHRLICH, Eugen. Das zwingende und nichtzwingende Recht im Bürgerlichen Gesetzbuch für das Deutsche Reich. Aalen: Scientia, 1970.

ELLICKSON, Robert C., ROSE, Carol M., ACKERMAN, Bruce A. Perspectives on property law. 3. ed. [S.1.]: Aspen, 2002.

ENGISCH, Karl. Die Idee der Konkretisierung in Recht und Rechtswissenschaft unserer Zeit. 2. ed. Heidelberg: Winter, 1968.

ENGISCH, Karl. Introdução ao pensamento jurídico. Trad. J. Baptista Machado. 7. ed. Lisboa: Calouste Gulbenkian, 1996. 
ENNECCERUS, Ludwig; NIPPERDEY, Hans Carl. Allgemeiner Teil des bürgerlichen Rechts. 15. ed. Tübingen: J. C. B. Mohr, 1960, 2v.

ERMAN, Walter; WESTERMANN, Harm Peter; PALM, Heinz. Bürgerliches Gesetzbuch: Handkommentar. 12. ed. Köln: Dr. Otto Schmidt, 2008.

ESPÍNOLA, Eduardo. Dos contratos nominados no direito civil brasileiro. Rio de Janeiro: Gazeta Judiciária, 1953.

ESPÍNOLA, Eduardo. Os direitos reais limitados ou direitos sobre a coisa alheia e os direitos reais de garantia no Direito Civil brasileiro. Rio de Janeiro: Conquista, 1958.

ESPÍNOLA, Eduardo. Posse, propriedade, compropriedade ou condomínio, direitos autorais. Rio de Janeiro: Conquista, 1956.

ESSER, Josef. Grundsatz und Norm in der richterlichen Fortbildung des Privatrechts. 3. ed. Tübingen: Mohr, 1974.

ESSER, Josef; SCHMIDT, Eike. Schuldrecht: Allgemeiner Teil. 6. ed. Heidelberg: C. F. Müller, 1984, v.1.

FACHIN, Luis Edson. O estatuto civil da clausura real. In: Revista dos Tribunais 721, 1995, p.49-51.

FEENSTRA, Robert. Legal Scholarship and Doctrines of Private Law: 13th - 18th Centuries. Hampshire: Variorum, 1996.

FELGENTRAEGER, Wilhelm. Friedrich Carl von Savignys Einfluss auf die Uebereignungslehre. Leipzig: Deichert, 1927.

FERRARA, Francesco. Trattato di diritto civile italiano. Roma: Athenaeum, 1921, v.1.

FERRI, Giovanni Batista. Causa e tipo nella teoria del negozio giuridico. Milano: Giuffrè, 1968.

FLUME, Werner. Allgemeiner Teil des bürgerlichen Rechts: Das Rechtsgeschäft. 3. ed. Berlin: Springer, 1979.

FLUME, Werner. El negocio jurídico. Trad. de J. M. Miquel González e E. Gómez Calle. Madrid: Fundación Cultural del Notariado, 1998.

FOËX, Bénédict. Le numerus clausus des droits réels en matière mobilière. Paris, Payot, 1987. 
FRÄNZER, Albert. Time-sharing von Ferienhäusern: Zum Problem der Zulässigkeit in der Bundesrepublik Deutschland unter Berücksichtigung der Praxis in den USA und Großbritannien. Münster: Waxmann, 1990.

FRANZONI, Massimo. Degli effetti del contratto. In: SCHLESINGER, Piero. Il Codice Civile: Commentario. Milano: Giuffrè, 1999, v.2.

FREITAS GOMES, Luiz Roldão de. Nota sobre o direito das coisas no Projeto do Código Civil. In: Revista de direito do Tribunal de Justiça do Rio de Janeiro 45, 2000, p.6073.

FREITAS GOMES, Luiz Roldão de. O estatuto da propriedade perante o novo ordenamento constitucional brasileiro. In: Revista Forense 309, 1990, p.25-32.

FREYFOGLE, Eric T. The tragedy of fragmentation. In: Valparaiso University Law Review 36, 2002, p.307-337.

FÜLLER, Jens Thomas. Eigenständiges Sachenrecht? Tübingen: Mohr Siebeck, 2006.

FURTNER, Georg. Die rechtsgeschäftliche Verfügungsbeschränkung und ihre Sicherung. In: Neue juristische Wochenschrift 19.1, 1966, p.182-9.

GÄFGEN, Gérard. Entwicklung und Stand der Theorie der Property Rights: Eine kritische Bestandaufnahme. In: NEUMANN, Manfred (hrsg). Ansprüche, Eigentums- und Verfügungsrechte: Arbeitstagung des Vereins für Socialpolitik - Gesellschaft für Wirtschafts- und Sozialwissenschaften in Basel vom 26. - 28. September 1983. Berlin: Duncker und Humblot, 1984, p.43-62.

GALGANO, Francesco. Il negozio giuridico. In: CICU, Antonio; MESSINEO, Francesco; MENGONI, Luigi. (org.). Trattato di diritto civile e commerciale. Milano: Giuffrè, 1988, v.3.

GAlletTO, Tomaso. Proprietà immobiliare urbana. In: Digesto delle discipline privatistiche - sezione civile 15, 1998, p.468-502.

GAMBARO, Antonio. Il diritto di proprietà. In: CICU, Antonio; MESSINEO, Francesco; MENGONI, Luigi. (org.). Trattato di diritto civile e commerciale. Milano: Giuffrè, 1995, v.8.2.

GAMBARO, Antonio. La proprietà: Beni, proprietà, comunione. Milano: Giuffrè, 1990.

GAMBARO, Antonio. Proprietà in diritto comparato. In: Digesto delle discipline privatistiche - sezione civile 15, 1998, p.502-25.

GARCEZ, Martinho. Direito das coisas. Rio de Janeiro: Jacintho Ribeito dos Santos, 1915. 
GARCIA, Lysippo. O registro de imóveis: a inscripção. Rio de Janeiro: Francisco Alves, 1927.

GARCIA, Lysippo. O registro de imóveis: a transcripção. Rio de Janeiro: Francisco Alves, 1922.

GARCIA, Lysippo. Registros públicos e registros de immoveis. Rio de Janeiro: Casa Vallelle, 1929.

GERNHUBER, Joachim. Drittwirkungen im Schuldverhältnis kraft Leistungsnähe: Zur Lehre von den Verträgen mit Schutzwirkung für Dritte. In: Festschrift für Arthur Nikisch. Tübingen: Mohr Siebeck, 1958, p.249-74.

GINOSSAR, Shalom. Droit réel, propriété et créance: Élaboration d'un système rationnel des droits patriomoniaux. Paris: LGDJ, 1960.

GINOSSAR, Shalom. Pour une meilleure définition du droit réel et du droit personnel. In: Revue trimestrielle de droit civil 60, 1962, p.573-89.

GIORGIANNI, Michele. Contributo alla teoria dei diritti di godimento su cosa altrui. Ora in: GIORGIANNI, Michele. Raccolta di scritti: Itinerari giuridici tra pagine classiche e recenti contributi. Padova: CEDAM, 1996, p.3-204.

GIUFFRÈ, Vincenzo. L'emersione dei “iura in re aliena” ed il dogma del "numero chiuso'. Napoli: Jovene, 1992.

GIVERDON, Claude; SALVAGE GEREST, Pascale. Propriétés et droits réels. In: Revue trimestrielle de droit civil 2, 1987, p.368-81.

GOMES, Orlando. Contratos. 3 ed. Rio de Janeiro: Forense, 2000.

GOMES, Orlando. Direitos reais. 19. ed. Rio de Janeiro: Forense, 2005.

GOMES, Orlando. Escritos menores. São Paulo: Saraiva, 1981.

GOMES, Orlando. Introdução ao direito civil. 18. ed. Rio de Janeiro: Forense, 2001.

GOMES, Orlando. Novos temas de direito civil. Rio de Janeiro: Forense, 1983.

GOMES, Orlando. Raízes históricas e sociológicas do Código Civil brasileiro. São Paulo: Martins Fontes, 2003.

GORDLEY, James. Foundations of Private Law: Property, Tort, Contract, Unjust Enrichment. Oxford: Oxford University, 2006.

GRALKA, Peter. Time-sharing bei Ferienhäusern und Ferienwohnungen. Köln: Carl Heymanns, 1986. 
GRANELLI, Carlo. Le cosidette vendite in multiproprietà. In: Rivista di diritto civile 2 , 1979, p.686-93.

GRASSETTI, Cesare. Del negozio fiduciario e della sua ammissibilità nel nostro ordinamento. In: Rivista di diritto commerciale 1, 1936, p.345-67.

GRAZIANI, Carlo Alberto. Il riconoscimento dei diritti reali: Contributo alla teoria dell'atto ricognitivo. Padova: Cedam, 1979.

GROSSI, Paolo. Il dominio e le cose: Percezioni medievali e moderne dei diritti reali. Milano: Giuffrè, 1992.

GROSSI, Paolo. La proprietà e le proprietà nell'oficina dello storico. In: CORTESE, Ennio (cur.). La proprietà e le proprietà. Milano: Giuffrè, 1988, p.205-72.

GROSSI, Paolo. Le situazioni reali nell'esperienza giuridica medievale: Corso di storia del diritto. Padova, Cedam, 1968.

GROSSI, Paolo. Proprietà in generale: Diritto intermedio. In: Enciclopedia del diritto 37, 1968, p.226-254.

GROSSI, Paolo. Un altro modo di possedere: L'emersione di forme alternative di proprietà alla coscienza giuridica postunitaria. Milano: Giuffrè, 1977.

GROßFELD, Bernard; GERSCH, Hans-Georg. Zeitliche Grenzen von privaten Schuldverträgen. In: Juristenzeitung 43, 1988, p.937-46.

GRUNDMANN, Stefan. Der Treuhandvertrag: Insbesondere die werbende Treuhand. München: C. H. Beck, 1997.

GUARNERI, Attilio. Diritti reali e diritti di credito: Valore attuale di uma distinzione. Padova: CEDAM, 1979.

GUIMARÃES, Jackson Rocha. O novo Código Civil e o direito das coisas. In: Revista dos Tribunais 798, 2002, p.51-64.

GURGEL, J. do Amaral. Registros públicos: Legislação, jurisprudência e doutrina. São Paulo: Saraiva, 1929.

HÄBERLE, Peter. Vielfalt der Property Rights und der verfassungsrechtliche Eigentumsbegriff. In: NEUMANN, Manfred (hrsg). Ansprüche, Eigentums- und Verfügungsrechte: Arbeitstagung des Vereins für Socialpolitik - Gesellschaft für Wirtschafts- und Sozialwissenschaften in Basel vom 26. - 28. September 1983. Berlin: Duncker und Humblot, 1984, p.63-102. 
HABERMAS, Jürgen. Facticidad y validez: Sobre el derecho y el Estado democrático de derecho em términos de teoria del discurso. Trad. de M. Redondo. 3. ed. Madri: Trotta, 2001.

HABERSACK, Mathias. Vertragsfreiheit und Drittinteressen: Eine Untersuchung zu den Schrancken der Privatautonomie unter besonderer Berücksichtigung der Fälle typischerweise gestörter Vertragsparität. Berlin: Duncker und Humblot, 1992.

HADDING, Walther. Vertraglicher Abtretungsausschluss Überlegungen de lege lata und de lege ferenda. In: Zeitschrift für Wirtschaft und Bankrecht, 1988, p.9-15.

HAEDICKE, Maximilian. Rechtskauf und Rechtsmängelhaftung: Forderungen, Immaterialgüterrechte und sonstige Gegenstände als Kaufobjekte und das reformierte Schuldrecht. Tübingen: Mohr Siebeck, 2003.

HANSMANN, Henry; KRAAKMAN, Reinier. Property, contract and verification: The numerus clausus problem and the divisibility of rights. In: Journal of Legal Studies 31, 2002, p.373-407.

HART, Herbert. The concept of Law. 2. ed. Oxford: Clarendon, 1994.

HASSEMER, Winfried. Tatbestand und typus. Berlim, C. Heymanns, 1968.

HATTENHAUER, Hans. Conceptos fundamentales del derecho civil: Introducción histórico-dogmática. Trad de G. Hernández. Barcelona: Ariel, 1987.

HATTENHAUER, Hans. Die Entdeckung der Verfügungsmacht: Studien zur Geschichte der Grundstücksverfügung im deutschen Recht des Mittelalters. Hamburg: Joachim Heitmann, 1969.

HATTENHAUER, Hans. Über vereintes und entzweites Eigentum. In: BAUR, Jürgen F. Das Eigentum. Göttingen: Vandenhoeck und Ruprecht, 1989, p.83-101.

HECK, Philipp. Grundriss des Sachenrechts. Aalen: Scientia, 1960.

HEDEMANN, Justus Wilhelm. Die Fortschritte des Zivilrechts im 19. Jahrhundert. Berlin: Heymann, 1910, v.1.

HEDEMANN, Justus Wilhelm. Sachenrecht des Bürgerlichen Gesetzbuches. 2. ed. Berlin: Walter de Gruyter, 1950.

HEISE, Georg Arnold. Grundriss eines Systems des gemeinen Civilrechts zum Behuf von Pandecten-Volesungen 3. ed. Heidelberg: Mohr und Winter, 1819.

HELLER, Michael A. The boundaries of private property. In: Yale Law Journal 108, 1999, p.1163-1223. 
HENKEL, Heinrich. Einführung in die Rechtsphilosophie: Grundlagen des Rechts. München: C. H. Beck, 1964.

HEYDE, Joh's Erich. Typus: Ein Beitrag zur Typologik. In: Studium Generale: Zeitschrift für die Einheit der Wissenschaft im Zusammenhang ihrer Begriffsbildungen und Forschungsmethoden 5, 1952, p.235-47.

HILDENBRAND, Thomas; KAPPUS, Andreas; MÄSCH, Gerald. Time-sharing und Teilzeit-Wohnrechtegesetz. Stuttgart: Richard Boorberg, 1997.

HÖFLING, Wolfram. Vertragsfreiheit: Eine grundrechtsdogmatische Studie. Heidelberg: C. F. Müller, 1991.

HOHFELD, Wesley Newcomb. Fundamental Legal Conceptions as Applied in Judicial Reasoning. New Jersey: The Lawbook Exchange, 2000.

HOLTZ, Walter. Das Anwartschaftsrecht aus bedingten Übereignung als Kreditsicherungsmittel. Berlin: Heymann, 1933.

HONORÉ, A. M. Rights of Exclusion and Immunities against Divesting. In: Tulane Law Review 34, 1959-60, p.453-68.

HOPP, Ruldolf. Eigentumsvorbehalt und Anwartschaftsrecht. Berlin: Ebering, 1938.

IRTI, Natalino. L’ordine giuridico del mercato. 4. ed. Roma: Laterza, 2001.

IRTI, Natalino. Letture bettiane sul negozio giuridico. Milano: Giuffrè, 1991.

JAUERNIG, Othmar. BGB mit allgemeinem Gleichbehandlungsgesetz: Kommentar. München: C. H. Beck, 2007.

JOHOW, Reinhold. Entwurf eines Bürgerlichen Gesetzbuches für das Deutsche Reich: Sachenrecht. Berlin: Reichsdruckerei, 1880, 3v. In: SCHUBERT, Werner (hrsg). Die Vorlagen der Redaktoren für die erste Komission zur Ausarbeitung des Entwurfs eines Bürgerlichen Gesetzbuches: Sachenrecht. Berlin: Walter de Gruyter, 1982, p.616, v.1.

JUNQUEIRA DE AZEVEDO, Antonio. Estudos e pareceres de direito privado. São Paulo: Saraiva, 2004.

JUNQUEIRA DE AZEVEDO, Antonio. Negócio jurídico e declaração negocial: Noções gerais e formação da declaração negocial. São Paulo: Saraiva, 1986.

JUNQUEIRA DE AZEVEDO, Antonio. Negócio jurídico: Existência, validade e eficácia. 4. ed. São Paulo: Saraiva, 2002. 
KASER, Max. Das römische Privatrecht: Das altrömische, das vorklassische und klassische Recht. 2. ed. München: C. H. Beck, 1971.

KASER, Max. Das römische Privatrecht: Die nachklassischen Entwicklungen. 2. ed. München: C. H. Beck, 1975.

KASER, Max. Römisches Privatrecht. München: C. H. Beck, 1992.

KEGEL, Gerhard. Nemo ,minus' iuris transferre potest, quam ipse habet, oder warum Erbteilungsverbote so kraftlos sind. In: WARDA, Günter et alii. Festschrift für Richard Lange zum 70. Geburtstag. Berlin: Walter de Gruyter, 1976, p.927-41.

KEGEL, Gerhard. Verpflichtung und Verfügung. In: FLUME, Werner et alii (hrsg.) Festschrift für F. A. Mann zum 70. Geburtstag. München: C. H. Beck, 1977, p.57-86.

KELSEN, Hans. Teoria generale del diritto e dello stato. Trad. de S. Cotta e G. Treves. 5. ed. Milano: Etas Libri, 1966.

KHULEN, Lothar. Typuskonzeptionem im der Rechtstheorie. Leipzig, Duncker \& Humblot, 1977.

KLEMM, Peter Christoph. Eigentum und Eigentumsbeschränkungen in der Doktrin des usus modernus pandectarum. Basel: Helbing und Lichtenhahn, 1984.

KLUN, M. Un modello di multiproprietà: La proprietà azionaria. In: Le società, 1984, p.858-.

KOHLER, Josef. Lehrbuch des Burgerlichen Rechts. Berlim, Heymanns, 1904, v.1.

KOHLER, Josef. Preisbestimmung und $\S 826$ BGB. In: Archiv für bürgerliches Recht 29, 1906, p.140-56.

KOHLER, Jürgen. Das Verfügungsverbot gemäß § 938 Abs. 2 ZPO im Liegenschaftsrecht: Eine Untersuchung zum System der Immobiliarrechtssicherung. Köln: Heymanns, 1984.

KOLLHOSSER, Helmut. Die Verfügungsbefugnis bei sog. Sperrkonten. In: Zeitschrift für Wirtschaftsrecht, 1984, p.389-97.

KOSCHAKER, Paul. Europa und das römische Recht. 4. ed. München: C. H. Beck, 1966.

KRAWIELICKI, Robert. Grundlagen des Bereicherungsanspruchs. Aalen: Scientia, 1964.

KROESCHELL, Karl. Zur Lehre vom ,germanischen“ Eigentumsbegriff. In: KROESCHELL, Karl et alii (hrsg.). Rechtshistorische Studien: Hans Thieme zum 70. Geburtstag. Köln: Böhlau, 1977, p.34-71. 
KRÜGER-NIELAND, Gerda; ZÖLLER, Hannelore. Das BGB mit besonderer Berücksichtigung der Rechtsprechung des Recihsgerichts und des Bundesgerichtshofes (RGR Kommentar): $\$ \S$ 1-240. 12. ed. Berlin: Walter de Gruyter, 1982.

KÜBLER, Friedrich. Was leistet die Konzeption der Property Rights für aktuelle rechtspolitische Probleme? In: NEUMANN, Manfred (hrsg). Ansprüche, Eigentumsund Verfügungsrechte: Arbeitstagung des Vereins für Socialpolitik - Gesellschaft für Wirtschafts- und Sozialwissenschaften in Basel vom 26. - 28. September 1983. Berlin: Duncker und Humblot, 1984, p.105-122;

LACERDA DE ALMEIDA, Francisco de Paula. Direito das cousas. Rio de Janeiro: J. Ribeiro dos Santos, 1908, 2v.

LARENZ, Karl. Grundfragen der neuen Rechtswissenschaft. 1935.

LARENZ, Karl. Lehrbuch des Schuldrechts: Allgemeiner Teil. 14. ed. München: C. H. Beck, 1987.

LARENZ, Karl. Lehrbuch des Schuldrechts: Allgemeiner Teil. München: C. H. Beck, 1982, v.1.

LARENZ, Karl. Metodologia da ciência do direito. Trad. J. Lamego. 3 ed. Lisboa: Fundação Calouste Gulbenkian, 1997.

LARENZ, Karl; WOLF, Manfred. Allgemeiner Teil des bürgerlichen Rechts. 8. ed. München: C. H. Beck, 1997.

LARENZ, Karl; WOLF, Manfred. Allgemeiner Teil des bürgerlichen Rechts. 9. ed. München: C. H. Beck, 2004.

LAURENT, François. Principes de droit civil français. 3. ed. Bruxelles: BruylantChristophe, 1878, v.6.

LEÃES, Luis Gastão Paes de Barros. Comentários à lei das sociedades anônimas. São Paulo: Saraiva, 1980, v.2.

LEENEN, Detlef. Typus und Rechtsfindung: Die Bedeutung der typologischen Methode für die Rechtsfindung dargestellt am Vertragsrecht des BGB. Berlin: Duncker und Humblot, 1971.

LEHMANN, Heinrich. Allgemeiner Teil des Bürgerlichen Gesetzbuches. 4. ed. Berlin: Walter de Gruyter, 1933.

LENZ, Christoph. Das Time-sharing. Münster: Westfälischen Wilhelms-Universität, 2000. 
LEVIS, Marc. L'opposabilité du droit réel: De la sanction judiciaire des droits. Paris: Economica, 1989.

LEVMORE, Saul. Two stories about the evolution of property rights. In: Journal of Legal Studies 31, 2002, p.421-438.

LIEBS, Rüdiger. Die unbeschränkbare Verfügungsbefugnis. In: Archiv für die civilistische Praxis 175, 1975, p.1-43.

LIMA MARQUES, Claudia. Contratos de time-sharing e a proteção dos consumidores: Crítica ao direito civil em tempos pós-modernos. In: Revista de direito do consumidor 22, 1997, p.64-86.

LUMIA, Giuseppe. Lineamenti di teoria e ideologia del diritto. 3. ed., Milano: Giuffrè, 1981 (com adaptações e modificações às pp.102-123 por Alcides Tomasetti Jr.).

MACKELDEY, Ferdinand. Elementos de direito romano contendo a teoria das institutas precedida de uma introdução ao estudo do direito romano. Trad. de A. Bento de Faria. Rio de Janeiro: Jacintho Ribeiro dos Santos, 1907.

MACKELDEY, Ferdinand. Manuel de droit romain. Trad. de J. Beving. Bruxelas: Societé Typographique Belge, 1837.

MAGALHÃES, Vilobaldo Bastos de. Compra e venda e sistemas de transmissão da propriedade. Rio de Janeiro: Forense, 1981.

MAHONEY, Julia D. Perpetual restrictions on land and the problem of the future. In: Virginia Law Review 88, 2002, p.739-787.

MAIA, Paulo Carneiro. A retrovenda. São Paulo, Saraiva, 1955.

MAIORCA, Carlo. La cosa em senso giuridico: Contributo alla critica di um dogma. Torino: Istituto Giuridico della Reggia Università, 1937.

MANIGK. Alfred. Das rechtswirksame Verhalten: Systematischer Aufbau und Behandlung der Rechtsakte des Bürgerlichen und Handelsrechts. Berlin: Walter de Gruyter, 1939.

MARCELINO, Andreia Oliveira. Responsabilidade civil dos hotéis e do sistema de multipropriedade imobiliária (time-sharing). In: Revista dos Tribunais 810, 2003, p.739-52.

MARTIGNETTI, Giuliano. Propriedade. In: BOBBIO, Norberto; MATTEUCCI, Nicola; PASQUINO, Gianfranco. Dicionário de política. $11^{\mathrm{a}}$ ed., Brasília, UNB, 1998, v.2.

MATTEI, Ugo. I diritti reali: La proprietà. In: SACCO, Rodolfo. Trattato di diritto civile. Torino: UTET, 2001, v.4, 1. 
MATTEI, Ugo. Proprietà, in Digesto delle discipline privatistiche - sezione civile 15, 1998, p.432-456.

MAYER-MALY, Theo. Eigentum und Verfügungsrechte in der neueren deutschen Rechtsgeschichte. In: NEUMANN, Manfred (hrsg). Ansprüche, Eigentums- und Verfügungsrechte: Arbeitstagung des Vereins für Socialpolitik - Gesellschaft für Wirtschafts- und Sozialwissenschaften in Basel vom 26. - 28. September 1983. Berlin: Duncker und Humblot, 1984, p.25-40.

MEDICUS, Dieter. Allgemeiner Teil des BGB: Ein Lehrbuch. 6. ed. Heidelberg: C. F. Müller, 1994.

MEDICUS, Dieter. Schuldrecht: Allgemeiner Teil. 17. ed. München: C. H. Beck, 2006.

MENEZES CORDEIRO, Antonio. Da boa-fé no direito civil. Coimbra: Almedina, 1984, v.2.

MENEZES CORDEIRO, Antonio. Direitos reais. Lisboa: Lex, 1979.

MERRILL, Thomas W. The Demsetz thesis and the evolution of property rights. In: Journal of Legal Studies 31, 2002, p.331-337.

MERRILL, Thomas W. The landscape of constitutional property. In: Virginia Law Review 86, 2000, p.885-999.

MERRILL, Thomas W.; SMITH, Henry E. Optimal standardzation in the law of property: The numerus clauses principle. In: Yale Law Journal 110, 2000, p.1-70.

MERRILL, Thomas W.; SMITH, Henry E. The property/contract interface. In: Columbia Law Review 101, 2001, p.773-852.

MERRILL, Thomas W.; SMITH, Henry E. What happened to property in law and economics? In: Yale Law Journal 111, 2001, p.357-398.

MERRYMAN, John Henry. Ownership and estate: Variations on a theme by Lawson. In: Tulane Law Review 48, 1974, p.916-945.

MERRYMAN, John Henry. Policy, Autonomy, and the Numerus Clausus in Italian and American Property Law. In: American Journal of Comparative Law 12, 1963, p.22431.

MESSINEO, Francesco. Il contratto in genere. Milano: Giuffrè, 1968, v.1.

MESTRE, Jacques; PUTMAN, Emmanuel; BILLIAU, Marc. Droit commun des sûretés réelles: Théorie générale. In: GHESTIN, Jacques. Traité de droit civil. Paris: LGDJ, 1996. 
MOCCIA, Luigi. La sicurezza degli acquisti immobiliari: Figure di usucapione e sistemi di pubblicita immobiliare nella prospettiva del diritti privato europeo. In: Rivista trimestrale di diritto e procedura civile 1, 1992, p.129-81.

MOLINARIO, Alberto D. De las relaciones reales. Buenos Aires: La Ley, 1965.

MOLKENTELLER, Dieter Haag. Die These vom dinglichen Vertrag: Zur formalen Struktur der Eigentumsübertragung nach § 929 Satz 1 BGB. Frankfurt am Main: Peter Lang, 1991.

MOREIRA ALVES, José Carlos. A retrovenda. 2. ed. São Paulo: Revista dos Tribunais, 1987.

MOREIRA ALVES, José Carlos. Da alienação fiduciária em garantia. São Paulo: Saraiva, 1973.

MOREIRA ALVES, José Carlos. Posse. Rio de Janeiro, Forense, 1999, 2 v.

MOSTIN, Corinne; FERON, Benoit. Le timesharing: Une nouvelle forme de proprieté? In: Annales de droit de Louvain 1, 1994, p.3-87.

MOTA PINTO, Carlos Alberto da. Cessão de contrato. São Paulo: Saraiva, 1985.

MOTA PINTO, Carlos Alberto da. Teoria geral do direito civil. 3. ed. Coimbra: Coimbra, 1999.

Motive zu dem Entwurfe eines bügerlichen Gesetzbuches für das deutsche Reich: Sachenrecht. 2. ed. Berlin: Guttentag, 1986, p.262, v.3.).

MÜLLER-FREIENFELS, Wolfram. Die Vertretung beim Rechtsgeschäft. Tübingen: Mohr, 1955.

MUMMENHOFF, Winfried. Vertragliches Abtretungsverbot und Sicherungszession im deutschen, österreichischen und us-amerikanischen Recht. In: Juristenzeitung, 1979, p.425-30.

NATUCCI, Alessandro. La tipicità dei diritti reali. 2. ed. Padova: CEDAM, 1988.

NEUNER, Carl. Wesen und Arten der Privatrechtsverhältnisse. Kiel: Schwers, 1866.

NOBRE JUNIOR, Edílson Pereira. A posse e a propriedade no novo Código Civil. In: Revista Forense 364, 2002, p.67-82.

NÖRR, Knut Wolfgang. Zwischen den Mühlsteinen: Eine Privatrechtsgeschichte der Weimarer Republik. Tübingen: Mohr Siebeck, 1988.

NORTH, Douglas. Institutions, Institutional Change and Economic Performance. Cambridge: Cambridge, 1990. 
OERTMANN, Paul. Der Dinglichkeitsbegriff. In: Jahrbücher für die Dogmatik des heutigen römischen und deutschen Privatrechts 31, 1892, p.415-67.

OERTMANN, Paul. Rechtsgeschäftliches Veräußerungsverbot und einstweilige Verfügung. In: Das Recht, 1916, p.58-63.

OERTMANN, Paul. Zur Struktur der subjektiven Privatrechte. In: Archiv für die civilistische Praxis 123, 1925, p.129-60.

OFTINGER, Karl. Die Vertragsfreiheit. In: Die Freiheit des Bürgers im schweizerischen Recht. Zürich: Polygraph., 1948, p.315-33.

OGRIS, Werner. Die Wissenschaft des gemeinen römischen Rechts und das österreichische Allgemeine bürgerliche Gesetzbuch. In: COING, Helmut; WILHELM, Walter. Wissenschaft und Kodifikation des Privatrechts im 19. Jahrhundert. Frankfurt am Main: Vittorio Klostermann, 1974, p.153-72, v.1.

OLIVEIRA ASCENSÃO, José de. A tipicidade dos direitos reais. Lisboa: S. e., 1968.

OLIVEIRA ASCENSÃO, José de. As relações jurídicas reais. Lisboa: Livraria Moraes, 1962.

OLIVEIRA ASCENSÃO, José de. Direito civil: Reais. 5. ed. Coimbra: Coimbra: 2000.

OLIVEIRA MACHADO, Joaquim de. Manual do official de registro geral e das hypothecas. Rio de Janeiro: B. L. Garnier, 1888.

OLIVEIRA MACHADO, Joaquim de. Novissima guia pratica dos tabeliães ou o notariado no Brasil e sua reforma. Rio de Janeiro: Garnier, 1887.

OLZEN, Dirk. Aktuelle zivilrechtliche Probleme des Eigentums. In: J. F. BAUR. Das Eigentum. Göttingen: Vandenhoeck und Ruprecht, 1989, p.103-24.

OSÓRIO DE AZEVEDO JR., José. Compromisso de compra e venda. 5. ed. São Paulo: Malheiros, 2006.

OVERSTAKE, Jean-Francis. Essai de classification des contrats spéciaux, Paris: LGDJ, 1969.

PAGENSTECHER, Ernst. Pandekten-Praktikum. Heidelberg: Vangel und Schmidt, 1860.

PALANDT, Otto et alii. Bürgerliches Gesetzbuch. 66. ed. München: C. H. Beck, 2007.

PALANDT, Otto et alii. Bürgerliches Gesetzbuch. 67. ed. München: C. H. Beck, 2008.

PAPAÑO, Ricardo José et alii. Derechos reales. 2. ed. Buenos Aires: Astrea, 2004, v.1. 
PARISI, Francesco. Entropy in property: In: American Journal of Comparative Law 50, 2002, p.595-632.

PATAULT, Anne-Marie. Introduction historique au droit des biens. Paris: PUF, 1989.

PELLERINO, Giovanni. L'idea di proprietà: Storia come evoluzione. Lecce: Pensa, 2004.

PENHA GONÇALVES, Augusto. Curso de direitos reais. 2. ed. Lisboa: Universidade Lusíada, 1993.

PENNER, John. E. The "bundle of rights" picture of property. In: UCLA Law Review 43, 1996, p.711-820.

PENNER, John E. The Idea of Property in the Law. Oxford: Oxford University Press, 1997.

PÉREZ LASALA, José Luis. Derechos reales y derechos de crédito: Consideración especial del arrendamiento. Buenos Aires: Depalma, 1967.

PEUKERT, Alexander. Güterzuordnung als Rechtsprinzip. Tübingen: Moher Siebeck, 2008.

PICKER, Eduard. Positive Forderungsverletzung und culpa in contrahendo: Zur Problematik der Haftungen, zwischen' Vertrag und Delikt. In: Archiv für die civilistische Praxis 183, 1983, p.369-520.

PLANIOL, Marcel; RIPERT, Georges. Traité élémentaire de droit civil. 12. ed. Paris: LGDJ, 1939, v.1.

POLANYI, Karl. The Great Transformation: The Political and Economic Origins of Our Time. 2. ed. Boston: Beacon Press, 2001.

PONTES DE MIRANDA, Francisco Cavalcanti. Comentários à Constituição de 1946. 2. ed. São Paulo: Max Limonad, 1953, v.4.

PONTES DE MIRANDA. Francisco Cavalcanti. Comentários à Constituição de 1967. São Paulo: Revista dos Tribunais, 1967, v.4.

PONTES DE MIRANDA, Francisco Cavalcanti. Comentários ao Código de Processo Civil. Rio de Janeiro: Forense, 1959, v.9.

PONTES DE MIRANDA. Francisco Cavalcanti Comentários ao Código de Processo Civil. Rio de Janeiro: Forense, 1962, v.15.

PONTES DE MIRANDA, Francisco Cavalcanti. Tratado de direito privado. Rio de Janeiro: Borsoi, 1954, v.1. 
PONTES DE MIRANDA, Francisco Cavalcanti. Tratado de direito privado. Rio de Janeiro: Borsoi, 1954, v.2.

PONTES DE MIRANDA. Francisco Cavalcanti. Tratado de direito privado. Rio de Janeiro: Borsoi, 1954, v.3.

PONTES DE MIRANDA. Francisco Cavalcanti. Tratado de direito privado. 3. ed. Rio de Janeiro: Borsoi, 1970, v.3.

PONTES DE MIRANDA. Francisco Cavalcanti. Tratado de direito privado. Rio de Janeiro: Borsoi, 1954, v.4.

PONTES DE MIRANDA, Francisco Cavalcanti. Tratado de direito privado. Rio de Janeiro: Borsoi, 1955, v.5.

PONTES DE MIRANDA. Francisco Cavalcanti. Tratado de direito privado. 3. ed. Rio de Janeiro: Borsói, 1970, v.5.

PONTES DE MIRANDA, Francisco Cavalcanti. Tratado de direito privado. Rio de Janeiro: Borsói, 1955, v.10.

PONTES DE MIRANDA, Francisco Cavalcanti. Tratado de direito privado. 3. ed. Rio de Janeiro: Borsoi, 1971, v.10.

PONTES DE MIRANDA, Francisco Cavalcanti. Tratado de direito privado. Rio de Janeiro: Borsoi, 1955, v.11.

PONTES DE MIRANDA. Francisco Cavalcanti. Tratado de direito privado. 3. ed. Rio de Janeiro: Borsói, 1971, v.11.

PONTES DE MIRANDA. Francisco Cavalcanti. Tratado de direito privado. 3. ed. Rio de Janeiro: Borsói, 1971, v.13.

PONTES DE MIRANDA, Francisco Cavalcanti. Tratado de direito privado. Rio de Janeiro: Borsoi, 1955, v.14.

PONTES DE MIRANDA. Francisco Cavalcanti. Tratado de direito privado. Rio de Janeiro: Borsoi, 1956, v.15.

PONTES DE MIRANDA, Francisco Cavalcanti. Tratado de direito privado. 3. ed. Rio de Janeiro: Borsoi, 1971, v.15.

PONTES DE MIRANDA, Francisco Cavalcanti. Tratado de direito privado. Rio de Janeiro: Borsoi, 1956, v.16.

PONTES DE MIRANDA. Francisco Cavalcanti. Tratado de direito privado. 2. ed. Rio de Janeiro: Borsoi, 1956, v.17 
PONTES DE MIRANDA. Francisco Cavalcanti. Tratado de direito privado. Rio de Janeiro: Borsói, 1957, v.18.

PONTES DE MIRANDA, Francisco Cavalcanti. Tratado de direito privado. Rio de Janeiro: Borsoi, 1957, v.19.

PONTES DE MIRANDA, Francisco Cavalcanti. Tratado de direito privado. Rio de Janeiro: Borsoi, 1958, v.23.

PONTES DE MIRANDA, Francisco Cavalcanti. Tratado de direito privado. Rio de Janeiro: Borsoi, 1959, v.24.

PONTES DE MIRANDA, Francisco Cavalcanti. Tratado de direito privado. Rio de Janeiro: Borsoi, 1959, v.25.

PONTES DE MIRANDA. Francisco Cavalcanti. Tratado de direito privado. 2 ed. Rio de Janeiro: Borsoi, 1962, v.28.

PONTES DE MIRANDA, Francisco Cavalcanti. Tratado de direito privado. Rio de Janeiro: Borsoi, 1960, v.39.

PONTES DE MIRANDA, Francisco Cavalcanti Tratado de direito privado. Rio de Janeiro: Borsoi, 1962, v.40.

PORTO, Sergio José. O projeto de Código Civil e o direito das coisas. In: Revista dos Tribunais 794, 2001, p.36-55.

POSNER, Richard. Economic Analysis of Law. 6. ed. New York: Aspen, 2003.

POUND, Roscoe. Lectures on the Philosophy of Freemasonry. Whitefish: Kessinger, 2007.

PROUDHON, Jean Baptiste Victor. Traité des droits d'usufruit, d'usage, d'habitation et de superficie. Bruxelles: H. Tarlier, 1833, v.1.

PUCHTA, Georg Friedrich . Vorlesungen über das heutige römische Recht. 4. ed. Leipzig: Tauchnitz, 1854.

PUCHTA, Georg Friedrich. Cursus der Institutionen. 9. ed. Leipzig: Breitkopf \& Haertel, 1881.

PUGLIATTI, Salvatore. Beni e cose in senso giuridico. Milano: Giuffrè, 1962.

PUGLIATTI, Salvatore. La proprietà nel nuovo diritto. Milano: Giuffrè, 1964.

PUGLIATTI, Salvatore. La trascrizione: L'organizzazione e l'attuazione della pubblicità patrimoniale. 2v. In: CICU, Antonio; MESSINEO, Francesco; MENGONI, Luigi. (org.). Trattato di diritto civile e commerciale. Milão, Giuffrè, 1989, v.14. 
PUGLIESE, Giovanni. Diritti reali. In: Enciclopedia del diritto 12, 1964, p.755-776.

RAIBLE, Adalbert. Vertragliche Beschränkung der Übertragung von Rechten: Eine Untersuchung zum Verhältnis von $\S \$ 413,399$ 2. Alt. BGB zu 1137 Satz 1 BGB. Tübingen: Mohr, 1969.

RAINER-WALZ, Wolfgang. Sachenrecht für Nicht-Sachen?: Kritik einer Systemanalogie. In: Kritische Vierteljahresschrift für Gesetzgebung und Rechtswissenschaft 1, 1986, p. 131-164.

RAISER, Ludwig. Dingliche Anwartschaften. Tübingen: Mohr, 1961.

RAKOB, Julia. Ausländische Mobiliarsicherungsrechte im Inland: Substitutionsfragen am Beispiel des US-amerikanischen Sicherungsrechtes nach Artikel 9 UCC. Heidelberg: C. Winter, 2001.

REALE, Miguel. O direito como experiência: Introdução à epistemologia jurídica. 2. ed. São Paulo: Saraiva, 2002.

REALE, Miguel; REALE JR., Miguel; AMARAL DUTRA, Pedro do. O sistema financeiro da habitação: Estrutura, dirigismo contratual e a responsabilidade do estado. In: ASSOCIAÇÃO BRASILEIRA DAS ENTIDADES DE CRÉDITO IMOBILIÁRIO E POUPANÇA (org.). A atividade de crédito imobiliário $e$ poupança. São Paulo: ABECIP, 1994.

REGELSBERGER, Ferdinand. Pandekten. Leipzig, Duncker \& Humblot, 1893.

REINHARDT, Rudolf. Die Vereinigung subjektiver und objektiver Gestaltungskräfte im Vertrage. In: Festschrift zum 70. Geburtstag von Walter Schmidt-Rimpler. Karlsruhe: Müller, 1957, p.115-38.

REPGEN, Tilman. Kein Abschied von der Privatautonomie: Die Funktion zwingenden Rechts in der Verbrauchsgüterkaufrichtlinie. Paderborn: Schöningh, 2001.

RESCIGNO, Pietro. Per uno studio sulla proprietà. In: Rivista di diritto civile 1, 1972, p.1-67.

RESCIGNO, Pietro. Proprietà in generale: Diritto privato. In: Enciclopedia del diritto 37, 1988, p.254-297.

RICCIO, Angelo. Il diritto di superficie, la proprietà superficiaria e la proprietà separata. In: Contratto e impresa 2, 1998, p.428-32.

RITTSTIEG, Helmut. La proprietà come problema fondamentale: Studio sull'evoluzione del diritto mercantile. Trad. it. de E. Caterini. Napoli: ESI, 2000. 
RITTSTIEG, Helmut. Zur Entwicklung des Grundeigentums. In: Juristenzeitung, 1983, p.161-7.

ROBINSON, Glen O. Personal property servitudes. In: University of Chicago Law Review 71, 2004, p.1449-1523.

ROBINSON, J. H. (org.). Readings in European History. Boston: Ginn, 1906, v.2.

RODOTÀ, Stefano. Il terribile diritto: Studi sulla proprietà privata. 2. ed. Bologna: il Mulino, 1990.

RODOTÀ, Stefano. Proprietà: Diritto vigente. In: Novissimo digesto italiano 14, 1967, p.125-140.

RODRIGUES PEREIRA, Lafayette. Direito das coisas. 6. ed. Rio de Janeiro: Freitas Bastos, 1956.

RODRIGUEZ, Agustín Washington. Los derechos reales y la inscripción registral. La Plata: LEP, 1986.

ROMAN GARCIA, Antonio. La tipicidad en los derechos reales: Autonomía privada en la creación, modificación y extinción de relaciones jurídico-reales. Sistema de numerus apertus; sistema de numerus clausus. Madri, Montecorvo, 1994.

ROMANO, Francesco. Diritto e obbligo nella teoria del diritto reale. Napoli: Morano, 1967.

ROMANO, Santi. Frammenti di um dizionario giuridico. Milano: Giuffrè, 1983.

ROPPO, Enzo. O contrato. Trad. de A. Coimbra e J. Gomes. Coimbra: Almedina, 1988.

ROPPO, Enzo. O contrato. Trad. de A. Coimbra e J. Gomes. Coimbra: Almedina, 1988.

ROPPO, Vincenzo. Il contratto del duemila. Torino: Giappichelli, 2002.

ROPPO, Vincenzo. Il contratto. Milano: Giuffrè, 2001.

ROSSELLO, Carlo. Modi di acquisto della proprietà a titolo originário. In: Rivista di diritto civile 6, 1994, p.687-98.

ROTHER, Werner. Die Erfüllung durch abstraktes Rechtsgeschäft. In: Archiv für die civilistische Praxis 169, 1969, p.1-33.

RUDDEN, Bernard. Economic Theory Vs. Property Law: The Numerus Clausus Problem. In: Oxford Essays in Jurisprudence 3, 1987, p.239-63. 
RÜFNER, Thomas. $\S \S$ 90-103. In: M. SCHMOECKEL, J. RÜCKERT, R. ZIMMERMANN (hrsg.). Historisch-kritischer Kommentar zum BGB: Allgemeiner Teil §§ 1-240. Tübingen: Mohr Siebeck, 2003.

SACCO, Rodolfo. Autonomia contrattuale e tipi. In: Rivista trimestrale di diritto e procedura civile 1, 1966, p.785-808.

SACCO, Rodolfo. Possesso in generale: Diritto privato. In: Enciclopedia del diritto 34, 1988, p.491-519.

SACCO, Rodolfo; DE NOVA, Giorgio. Il contratto. In: SACCO, Rodolfo (dir.). Trattato di diritto civile. 3 ed. Torino: UTET, 2004, v.2.

SALOMÃO FILHO, Calixto. Função social do contrato: Primeiras anotações. In: Revista de direito mercantil 132, 2003, p.7-24.

SAMPAIO FERRAZ JR., Tercio. Estudos de filosofia do direito: Reflexões sobre o poder, a liberdade, a justiça e o direito. 2. ed., São Paulo: Atlas, 2003.

SANTORO-PASSARELLI, Francesco. Diritti assoluti e relativi. In: Enciclopedia del diritto 12 , 1964, p.748-755.

SANTORO-PASSARELLI, Francesco. Dottrine generali del diritto civile. 9. ed. Napoli: Jovene, 2002.

SANTOS JR, E. Da responsabilidade civil de terceiro por lesão do direito de crédito. Coimbra: Almedina, 2003.

SATURNO, Angelo. La proprietà nell'interesse altrui nel diritto civile italiano e comparato. Napoli: ESI, 1999.

SCHALCH, Stefan. Time-sharing an Ferienimmobilien. Zürich: Schulthess, 1990.

SCHERRER, Werner. Die geschichtliche Entwicklung des Prinzips der Vertragsfreiheit. Basel: Helbing und Lichtenhahn, 1948.

SCHLOSSER, Hans. Außenwirkungen verfügungshindernder Abreden bei der rechtsgeschäftlichen Treuhand. In: Neue juristische Wochenschrift 23.1, 1970, p.681-7.

SCHOER, Karl. Origins of Junker Capitalism in Germany. In: Social Scientist 5, 1976, p.33-46.

SCHÖLLHORN, Peter; STEUBER, Werner. Warnung vor Time-sharing. WaldshutTiengen: Vetter, 1994.

SCHREIBER, Klaus. Sachenrecht. 2. ed. Stuttgart: Richard Boorberg, 1996. 
SCHULZ, Fritz. Principios del derecho romano. Trad. de Abellán Velasco. $2^{\mathrm{a}}$ ed. Madri, Civitas, 2000.

SCHWAB, Karl Heinz. Grundlegend zur Eigentumstheorie des Liberalismus. In: BRUNNER, Otto; CONZE, Werner; KOSELLECK, Reinhart. Geschichtliche Grundbegriffe: Historisches Lexikon zur politisch-sozialen Sprache in Deutschland. Stuttgart: Klett-Cotta, 1975, v.2.

SCHWAB, Karl Heinz; PRÜTTING, Hanns. Sachenrecht. 32. ed. München: C. H. Beck, 2006.

SCHWARZ, Roberto. Ao vencedor as batatas: Forma literária e processo social nos inícios do romance brasileiro. 5. ed. São Paulo: 34, 2000.

SCOGNAMIGLIO, Renato. Lezioni sul negozio giuridico. Bari: Laterza, 1962.

SEIFERT, Peter. Verfügungsfreiheit und rechtsgeschäftliches Veräußerungsverbot. Frankfurt am Main: Rechtswissenschaftliche Fakultät, 1966.

SERPA LOPES, Miguel Maria de. Curso de direito civil: Direito das coisas. 5. ed. Rio de Janeiro: Freitas Bastos, 2001.

SERPA LOPES, Miguel Maria de. Curso de direito civil: Fontes das obrigações, contratos. 7 ed. Rio de Janeiro: Freitas Bastos, 2001, v.3.

SERPA LOPES, Miguel Maria de. Tratado dos registos públicos. 5. ed. Rio de Janeiro: Freitas Bastos, 1962, v.2.

SERRA, Antonio. La circolazione delle partecipazioni sociali. In: Studi in tema di forma societaria, servizi pubblici locali e circolazione della richezza imprenditoriale. Torino: Giappichelli, 2007, p.229-39.

SIEBERT, Wolfgang. Das rechtsgeschäftliche Treuhandverhältnis: Ein dogmatischer und rechtsvergleichender Beitrag zum allgemeinen Treuhandproblem. Marburg: Elwert, 1933.

SILVA PEREIRA, Caio Mario da. Condomínio e incorporações. 2. ed. Rio de Janeiro: Forense, 1969.

SILVA PEREIRA, Caio Mario. Instituições de direito civil: Fontes das obrigações. 10 ed. Rio de Janeiro: Forense, 2002, v.10.

SILVA PEREIRA, Caio Mario. Instituições de direito civil: Posse. Propriedade. Direitos reais de fruição, garantia e aquisição. 17. ed. Rio de Janeiro: Forense, 2002, v.4.

SMITH, Henry E. Exclusion and property rules in the law of nuisance. In: Virginia Law Review 90, 2004, p.966-1049. 
SMITH, Henry E. Property and property rules. In: N.Y.U. Law Review 79, 2004, p.17191798.

SMITH, Henry E. Structured settlements as structures of rights. In: Virginia Law Review 88, 2002, p.1953-1974.

SMITH, Henry E. The language of property: Form, context, and audience. In: Stanford Law Review 55, 2003, p.1105-1191.

SMITH, Roger J. Plural Ownership. Oxford: Oxford University, 2005.

SOERGEL, Hans Th.; HEFERMEHL, Wolfgang. Kommentar zum BGB: Allgemeiner Teil $\S \S 104-240.13$. ed. Stuttgart: Kohlhammer, 1999.

SOHM, Rudolph. Der Gegenstand: Ein Grundbegriff des Bürgerlichen Gesetzbuches. Leipzig: Duncker und Humblot, 1905.

STADLER, Astrid. Gestaltungsfreiheit und Verkehrsschutz durch Abstraktion: Eine rechtsvergleichende Studie zur abstrakten und kausalen Gestaltung rechtsgeschäftlicher Zuwendungen anhand des deutschen, schweizerischen, österreichischen, französischen und US-amerikanischen Rechts. Tübingen: Mohr Siebeck, 1996.

STAMMLER, Rudolf. Theorie der Rechtswissenschaft. 2. ed. Aalen: Scientia, 1923.

STAUDER, Tobias. Die Verwirkung zivilrechtlicher Rechtspositionen: Die Linie der Rechtsprechung bei der Anwendung des Verwirkungstatbestandes. Frankfurt am Main: Peter Lang, 1995.

STOLFI, Giuseppe. Teoria del negozio giuridico. Padova: CEDAM, 1947.

STRACHE, Karl-Heinz. Das Denken in Standards: Zugleich ein Beitrag zur Typologik. Berlin: Duncker \& Humblot, 1968.

STRAUCH, Dieter. Das geteilte Eigentum in Geschichte und Gegenwart. In: BAUMGÄRTEL, Gottfried et alii (hrsg). Festschrift für Heinz Hübner zum 70. Geburtstag. Berlin: Walter de Gruyter, 1984, p.273-93.

STRUYCKEN, Teun Huib Desiderius. De Numerus Clausus in het Goederenrecht. Amsterdam: Kluwer, 2007.

SZTAJN, Rachel. Contrato de sociedade e formas societárias. São Paulo: Saraiva, 1989.

TAINE, Hippolyte. Les origines de la France contemporaine: La révolution. Paris: Hachette, 1878, v.1. 
TAMPONI, Michele. Proprietà terriera privata. In: Digesto delle discipline privatistiche sezione civile 15, 1998, p.527-538.

TARELLO, Giovanni. Appunti su 'obbligo'. In: Rivista trimestrale di diritto e procedura civile 1, 1966, p.217-63.

TARELLO, Giovanni. Storia della cultura giuridica moderna: Assolutismo e codificazione del diritto. Bologna: il Mulino, 1976.

TEIXEIRA DE FREITAS, Augusto. Código Civil: Esboço. Rio de Janeiro: Tipografia Universal de Laemmert, 1864.

TEIXEIRA DE FREITAS, Augusto. Consolidação das leis civis. 3. ed. Rio de Janeiro: B. L. Garnier, 1876.

TEIXEIRA DE FREITAS, Augusto. Vocabulário jurídico. In: TOMASETTI JÚNIOR, Alcides. Clássicos do Direito Brasileiro. São Paulo, Saraiva, 1983, 2v.

TEPEDINO, Gustavo. Multipropriedade imobiliária. São Paulo: Saraiva, 1993.

TEPEDINO, Gustavo; BODIN DE MORAES, Maria. A multipropriedade: Aspectos jurídicos. In: Revista Forense 294, 1986, p.787-824.

THIBAUT, Anton Friedrich Justus. Versuche über einzelne Theile der Theorie des Rechts. Jena: Johann Michael Mauke, 1801, v.2.

THON, August. Rechtsnorm und subjektives Recht. Weimar: Böhlau, 1878.

TIMM, Wolfram. Außenwirkungen vertraglicher Verfügungsverbote? In: Juristenzeitung 44.1, 1989, p.13-24;

TOMASETTI JR., Alcides Procedimento do direito de domínio e improcedência da ação reivindicatória. Favela consolidada sobre terreno urbano loteado. Função social da propriedade. In: Revista dos Tribunais 723, 1996, p.204-23.

TOMASETTI JR., Alcides. Comentários. In: OLIVEIRA, Juarez de. Comentários à Lei de Locação de Imóveis Urbanos. São Paulo: Saraiva, 1992.

TOMASETTI JÚNIOR, Alcides. A propriedade privada entre o direito civil e a Constituição. São Paulo, 2002.

TOSI, Isabelle. Acte translatif et titularité des droits. Paris: LGDJ, 2006.

TOULLIER, Charles Bonaventure Marie. Le droit civil français suivant l'ordre du Code. 3. ed. Bruxelles: Stapleaux, 1820, v.3

TREILHARD, Jean Baptiste. Recueil complet des travaux préparatoires du Code Civil. Paris: Videcoq, 1836, v.11. 
TROPLONG, Raymond Theodore. Le droit civil expliqué suivant l'ordre des articles du Code: De l'échange et du louage. Paris: Charles Hingray, 1840, v.1.

VAN ERP, Sjef. Comparative Property Law. In: REIMANN, Mathias; ZIMMERMANN, Reinhard. The Oxford Handbook of Comparative Law. Oxford: Oxford University, 2006, p.1044-70.

VANGEROW, Karl Adolph. Lehrbuch der Pandekten. 7. ed. Marburg: Elwert, 1863, v.1.

VIEGAS DE LIMA, Frederico. A multipropriedade imobiliária: Aspectos doutrinários e registrários. In: Revista trimestral de direito civil 32, 2007, p.73-110.

VILLEY, Michel. Preface historique. In: Archives de philosophie du droit: Les biens e les choses en droit 24, 1979, p.1-7.

VON GIERKE, Otto. Der Entwurf eines Bürgerlichen Gesetzbuchs und das Deutsche Recht. Leipzig: Duncker und Humblot, 1897.

VON GIERKE, Otto. Deutsches Privatrecht. München: Duncker und Humblot, 1885, v.1.

VON GIERKE, Otto. Deutsches Privatrecht. München: Duncker und Humblot, 1917, v.3.

VON HAGER, Johannes. Verkehrsschutz durch redlichen Erwerb. München: C. H. Beck, 1990.

VON HIPPEL, Fritz. Das Problem der rechtsgeschäftlichen Privatautonomie: Beiträge zu einem natürlichen System des privaten Verkehrsrechts und zur Erforschung der Rechtstheorie des 19. Jahrhunderts. Tübingen: Mohr Siebeck, 1936.

VON JHERING, Rudolf. Geist des römischen Rechts auf den verschiedenen Stufen seiner Entwicklung. 7. ed. Leipzig: Breitkopf und Härtel, 1923, v.2, t.2.

VON JHERING, Rudolf. Geist des römischen Rechts auf den verschiedenen Stufen seiner Entwicklung. 7. ed. Leipzig: Breitkopf und Härtel, 1926, v.2, t.1.

VON LÜBTOW, Ulrich. Hand wahre Hand: Historische Entwicklung, Kritik und Reformvorschläge. In: Festschrift der Juristischen Fakultät der Freien Universität Berlin zum 41. Deutschen Juristentag in Berlin. Berlin: Franz Vahlen, 1955, p.119237.

VON OLSHAUSEN, Eberhard. Die verwechselten Grunstücke oder § 242 BGB im Sachenrecht. In: Juristenzeitung 1983, p.288-91.

VON SAVIGNY, Friedrich Carl. System des heutigen römischen Rechts. Berlin: Veit, 1840, v.1.

VON SAVIGNY. System des heutigen römischen Rechts. Berlin: Veit, 1840, v.3. 
VON SOKOLOWSKI, Paul. Die Philosophie im Privatrecht: Sachbegriff und Körper in der klassichen Jurisprudenz und der modernen Gesetzgebung. Halle: Max Niemeyer, 1902, v.1.

VON STAUDINGER, Julius et alii. Kommentar zum Bürgerlichen Gesetzbuch mit Einführungsgesetz und Nebengesetzen: Einleitung zum Sachenrecht. \$§ 854-882. 14. ed. Berlin: De Gruyter, 2000, v.44.

VON STAUDINGER, Julius; KOHLER, Jürgen. J. von Staudingers Kommentar zum Bürgerlichen Gesetzbuch mit Einführungsgesetz und Nebengesetzen: Allgemeiner Teil §§ 134-163. Berlin: Sellier-de Gruyter, 2003.

VON STAUDINGER, Julius; SEILER, Hans Hermann. J. von Staudingers Kommentar zum Bürgerlichen Gesetzbuch mit Einführungsgesetz und Nebengesetzen: Einleitung zum Sachenrecht §§ 854-882. Berlin: Sellier-de Gruyter, 2007.

VON TUHR, Andreas. Der allgemeine Teil des deutschen bürgerlichen Rechts. Leipzig: Duncker \& Humblot, 1957, 2v., 3t.

VON TUHR, Andreas. Der allgemeine Teil des deutschen bürgerlichen Rechts. Leipzig: Duncker \& Humblot, 1910, v.1.

VON TUHR, Andreas. Die unwiderrufliche Vollmacht. In: MEILI, Friedrich (hrsg.). Festschrift für Paul Laband. Zürich: Füssli, 1908, p.45-96.

VON WEIZSÄCKER, Carl Christian. Was leistet die Property Rights Theorie für aktuelle wirtschaftspolitische Fragen? In: NEUMANN, Manfred (hrsg). Ansprüche, Eigentums- und Verfügungsrechte: Arbeitstagung des Vereins für Socialpolitik Gesellschaft für Wirtschafts- und Sozialwissenschaften in Basel vom 26. - 28. September 1983. Berlin: Duncker und Humblot, 1984, p.123-52

VON WÄCHTER, Carl-Georg. Handbuch des im Königreich Württemberg geltenden Privatrechts. Stuttgart: Metzler, 1842.

VON WÄCHTER, Carl Georg. Pandekten. Leipzig, Breitkopf und Härtel, 1881, v.1.

WAGNER, Eberhard. Absolutwirkung vertraglicher Abtretungsverbot gleich absolute Unwirksamkeit verbotswidriger Abtretung? In: Juristenzeitung, 1994, p.227-33.

WAGNER, Eberhard. Rechtsgeschäftliche Unübertragbarkeit und § 137 S. 1 BGB. In: Archiv für die civilistische Praxis 194, 1994, p.451-78.

WAGNER, Eberhard. Vertragliche Abtretungsverbot im System zivilrechtlicher Verfügungshindernisse. Tübingen: Mohr, 1994.

WANK, Rolf. Mißbrauch der Treuhandstellung und der Vertretungsmacht. In: Juristische Schulung, 1979, p.402-8. 
WEBER, Max. Economy and Society: An Outline of Interpretive Sociology. Trad. de G. Roth e C. Wittich (coords.). Berkeley: University of California, 1978, p.684, v.2.

WEBER, Max. Rechtssoziologie. 2. ed. Neuwied: Luchterhand, 1967.

WEITNAUER, Hermann. Die unverzichtbare Handlungsfreiheit. In: E. BÖKELMANN et alii. Festschrift für Friedrich Weber zum 70. Geburtstag. Berlin: Walter de Gruyter, 1975, p.429-40.

WEITNAUER, Hermann. Verdinglichte Schuldverhältnisse. In: CANARIS, ClausWilhelm; DIEDERICHSEN, Uwe. Festschrift für Karl Larenz zum 80. Geburtstag. München: C. H. Beck, 1983, p.705-21.

WESTERMANN, Harm Peter. Vertragsfreiheit und Typengesetzlichkeit im Recht der Personengesellschaften. Berlin: Springer, 1970.

WESTERMANN, Harry; WESTERMANN, Harm Peter; GURSKY, Karl-Heinz; EICKMANN, Dieter. Sachenrecht: Ein Lehrbuch. 7. ed. Heidelberg: C. F. Müller, 1998.

WIEACKER, Franz. Bodenrecht. Hamburg: Hanseatische Verlags-Anstalt, 1938.

WIEACKER, Franz. Privatrechtgeschichte der Neuzeit: Unter besonderer Berücksichtigung der deutschen Entwicklung. Göttingen: Vandenhoeck und Ruprecht, 1952.

WIEACKER, Franz. Wandlungen der Eigentumsverfassung. Hamburg: Hanseatische Verlags-Anstalt, 1935.

WIEACKER, Franz. Zum System des deutschen Vermögensrechts: Erwägungen und Vorschläge. Leipzig: Theodor Weicher, 1941.

WIEDEMANN, Herbert. Die Übertragung und Vererbung von Mitgliedschaftsrechten bei Handelsgesellschaften. München: C. H. Beck, 1965.

WIEGAND, Wolfgang. Die Entwicklung des Sachenrechts im Verhältnis zum Schuldrecht. In: Archiv für die civilistische Praxis 190, 1990, p.112-38.

WIEGAND, Wolfgang. Numerus clausus der dinglichen Rechte: Zur Entstehung und Bedeutung eines zentralen zivilrechtlichen Dogmas. In: Rechtshistorische Reihe 60, 1987, p.623-43.

WIEGAND, Wolfgang. Sachenrecht im Obligationenrecht. In: CARONI, Pio. Das Obligationenrecht 1883-1983. Bern: Haupt, 1984, p.107-37. 
WIEGAND, Wolfgang. Sachenrechtsmodernisierung. In: ADERHOLD, Lutz et alii (hrsg.). Festschrift für Harm Peter Westermann zum 70. Geburtstag. Köln: Dr. Otto Schmidt, 2008, p.731-44.

WIEGAND, Wolfgang. Zur Entwicklung der Pfandrechtstheorien im 19. Jahrhundert. In: Zeitschrift für Neuere Rechtsgeschichte, 1981, p.1-15.

WIEGAND, Wolfgang. Zur theoretischen Begründung der Bodenmobilisierung in der Rechtswissenschaft: Der abstrakte Eigentumsbegriff. In: COING, Helmut; WILHELM, Walter. Wissenschaft und Kodifikation des Privatrechts im 19. Jahrhundert: Die rechtliche und wirtschaftliche Entwicklung des Grundeigentums und Grundkredits. Frankfurt am Main: Vittorio Klostermann, 1976, p.118-55, v.3.

WIELAND, Carl Albert. Les droits réels dans le Code Civil suisse. Trad. de H. Bovay. Paris: M. Giard \& E. Brière, 1913 v.1.

WIESMANN, Martin. Zur Tragweite des § 137 BGB. Münster: Westfälischen WilhelmsUniversität, 1991.

WILHELM, Jan. Sachenrecht. 3. ed. Berlin: De Gruyter, 2007.

WILlOWEIT, Dietmar. Dominium und Proprietas: Zur Entwicklung des Eigentumsbegriffs in der mittelalterlichen und neuzeitlichen Rechtswissenschaft. In: Historisches Jahrbuch im Auftrag der Görres-Gesellschaft 94, 1974, p.131-56

WILLOWEIT, Dietmar. Historische Grundlagen des Privatrechts: Das Eigentum. In: Juristische Schulung 7, 1977, p.429-33.

WINDSCHEID, Bernard. Lehrbuch des Pandektenrechts. 6. ed. Frankfurt am Main: Rütten und Loening, 1887, v.1.

WINDSCHEID, Bernard. Lehrbuch des Pandektenrechts. 9. ed. Frankfurt am Main: Rütten \& Loening, 1906, v.1.

WIRTH, Carl Julius Gottfried. Beiträge zur Systematik des Civilrechts. Erlangen: Deichert, 1856.

WIRTZ, Alois. Die Zwangsvollstreckung in das Anwartschaftsrecht beim Kauf unter Eigentumsvorbehalt. Würzburg: Mayr, 1933.

WOLF, Manfred. Beständigkeit und Wandel im Sachenrecht. In: Neue Juristische Wochenschrift 42, 1987, p.2647-52.

WOLF, Manfred. Sachenrecht. 23. ed. München: C. H. Beck, 2007. 
WOLFF, Hans Julius. Typen im Recht und in der Rechtswissenschaft. In: Studium generale: Zeitschrift für die Einheit der Wissenschaft im Zusammenhang ihrer Begriffsbildungen und Forschungsmethoden 4, 1952, p.195-205.

WOLFF, Martin. Reichsverfassung und Eigentum. In: Festgabe der Berliner juristischen Fakultät für Wilhelm Kahl zum Doktorjubiläum am 19. April 1923. Tübingen: Mohr, 1923, p.3-30, v.4.

WOLFF, Martin; RAISER, Ludwig. Derecho de cosas. 2v. In: ENNECCERUS, Ludwig et alii. Tratado de derecho civil. Trad. de B. Pérez Gonzalez e J. Alguer. Barcelona: Bosch, 1971, v.4.

ZACHARIAE VON LINGENTHAL, Karl Salomo. Manuale del diritto civile francese. Trad. L. Barassi. Milano: Libraria, 1907, v.1.

ZÉNATI, Frédéric. Pour une rénovation de la théorie de la propriété. In: Revue trimestrielle de droit civil 92, 1993, p.305-23.

ZÉNATI, Frédéric. Proprieté et droits réels. In: Revue trimestrielle de droit civil 2, 1991, p.361-7.

ZÉNATI, Frédéric; REVET, Thierry. Les biens. 2. ed. Paris: PUF, 1997.

ZIMMERMANN, Reinhard. The Law of Obligations: Roman Foundations of the Civilian Tradition. Oxford: Clarendon, 1996.

ZWEIGERT, Konrad. Rechtsvergleichend-kritisches zum Gutgläubigen Mobiliarerwerb. In: Zeitschrift für ausländisches und internationales Privatrecht 23, 1958, p.1-20. 


\section{RESUMO}

\section{NUMERUS CLAUSUS DOS DIREITOS REAIS E AUTONOMIA NOS CONTRATOS DE DISPOSIÇÃO}

Esta tese analisa um regime jurídico convencionalmente designado "numerus clausus dos direitos reais", examinando-o sob três aspectos.

O primeiro deles concerne às funções que esse regime desempenha no interior do ordenamento jurídico. Em um sistema de direito patrimonial privado que promove a autonomia contratual e predispõe restrições jurídico-negociais ao poder de dispor, entre as quais se ressaltam os direitos subjetivos reais, o regime de numerus clausus se apresenta como uma previsão legal dos tipos de contratos que restringem o poder de dispor e, assim, modificam o poder de adquirir do sujeito passivo universal. Conquanto sofram essa modificação em sua esfera jurídica, esses sujeitos de direito não tomam parte na celebração daqueles contratos. De maneira que as funções do numerus clausus dirigem-se, fundamentalmente, ao concerto de um fenômeno de heteronomia privada: por meio de um "catálogo", o adquirente pode não apenas conhecer quais são os contratos que, a despeito de sua declaração jurídico-negocial, afetam os seus interesses econômico-sociais, mas também desconsiderar a eficácia, sobre si, dos contratos que, extrapolando aquele catálogo, circunscrevem-se, seguramente, a só quem, dele, foi parte.

Em segundo lugar, sustenta-se uma qualidade negativa e outra positiva no numerus clausus. Negativamente, esse regime jurídico se identifica por uma grave limitação na autonomia contratual, especialmente na autonomia dos contratos de disposição. Nesse sentido, e porque o poder de dispor não é uma posição jurídica exclusiva da titularidade de direitos subjetivos reais, assim como as conseqüências de suas restrições não despontam apenas no direito das coisas, não apenas a disposição contratual de direitos subjetivos reais, mas também a disposição contratual de créditos, de participações societárias e de propriedade imaterial submete-se, igualmente, a um numerus clausus. Essa circunstância remete a uma duplicidade de regimes de autonomia contratual no direito dos contratos: enquanto não há um tipo de contrato em gênero (tipicidade vinculativa) e 
predominam as regras cogentes (tipicidade fixa) para os contratos de disposição, os contratos obrigacionais obedecem a uma tipicidade aberta. Positivamente, por seu turno, o numerus clausus legitima uma poderosa técnica jurídica de oponibilidade de interesses econômico-sociais: o contrato de disposição. Selecionando um dos poucos tipos de contratos de disposição predispostos pela lei, os contratantes afetam, por meio da regra da prioridade e da imunidade contra disposição, a eficácia de contratos de cuja formação não tomam parte, sejam contratos subseqüentes, obrigacionais ou de disposição, sejam contratos precedentes, meramente obrigacionais.

Sem dúvida, o ordenamento jurídico apresenta outras técnicas jurídicas de oponibilidade de interesses econômico-sociais aos terceiros-adquirentes, geralmente ligadas a procedimentos de publicidade, tais como a boa-fé. Muito embora elas manifestem efeitos semelhantes, por vezes contradizendo o regime de numerus clausus, não se verifica uma derrogação desse último, identificada, por vezes, como uma "realização dos direitos obrigacionais". No fundo, em se tratando de fatos jurídicos inconfundíveis, as metódicas de argumentação e aplicação do direito, pressupostas em cada um deles, são, outrossim, diferentes. Essas diferenças correspondem, por fim, ao terceiro e último daqueles três aspectos sob os quais se analisa o numerus clausus. Efetua-se, para tanto, o estudo de dois casos representativos, colhidos da jurisprudência brasileira, a qual aplica ora esse último regime, ora a boa-fé, sem que isso signifique nenhuma contradição, uma vez que a excepcionalidade dessa última confirma o caráter do numerus clausus como a regulação motriz do tráfico jurídico, orientada à segurança da aquisição e à estabilidade de determinadas relações de intercâmbio dos bens econômicos. 


\section{ZUSAMMENFASSUNG}

\section{NUMERUS CLAUSUS DER DINGLICHEN RECHTE UND VERTRAGSFREIHEIT IN VERFÜGUNGSVERTRÄGEN}

Diese Dissertation untersucht den „Numerus Clausus der dinglichen Rechte“ unter drei verschiedenen Aspekten.

Der erste Aspekt betrifft die Funktion dieses Ordnungsprinzips innerhalb des Privatrechts. Das Privatrecht gewährleistet einerseits die Vertragsfreiheit, sieht aber zugleich auch rechtsgeschäftliche Verfügungsbeschränkungen vor, zu denen, so die hier vertretene These, insbesondere die beschränkt-dinglichen Rechte zählen. Der Grundsatz des Numerus Clausus wird als eine Typengebundenheit sowohl der vertraglichen Verfügungsbeschränkungen als auch der Gestaltungsmöglichkeit der Erwerbsmacht von Dritten erfasst. Deswegen ist die Funktion des Numerus Clausus eine Form der Regelung der privaten Fremdbestimmung: Durch einen abschließenden gesetzlichen Katalog von dinglichen Rechten weiß ein Erwerber nicht nur, welche Arten von Rechtsgeschäften unabhängig von seiner Beteiligung seinen Rechtskreis betreffen, sondern auch, welche Rechtsgeschäfte er vernachlässigen kann, weil sie außerhalb des Katalogs liegen.

Der zweite Aspekt betrifft eine negative und eine positive Seite des Numerus Clausus-Prinzips. Auf der einen Seite schränkt es die Vertragsfreiheit stark ein, insbesondere die Freiheit im Bereich der Verfügungsverträge. Folglich gibt es einen Numerus Clausus der Verfügungsverträge nicht nur von dinglichen Rechten, sondern auch von Forderungsrechten, Mitgliedschaftsrechten und Immaterialgüterrechten. Hinzu kommt, dass die Verfügungsmacht eine Rechtsstellung ist, die nicht nur zur Sachenrechtszuständigkeit gehört, ferner, dass die Konsequenzen ihrer rechtsgeschäftlichen Beschränkung nicht nur im Sachenrecht zu beobachten sind. Diese Eigenschaft des Numerus Clausus-Prinzips zeigt, dass der Grundsatz der Vertragsfreiheit nicht einheitlich $\mathrm{zu}$ verstehen ist: Auf der einen Seite bestehen Typenzwang und Typenfixierung der Verfügungsverträge, auf der anderern Seite die Typenfreiheit der Verpflichtungsverträge. 
Der positive Aspekt des Grundsatzes des Numerus Clausus besteht darin, dass er die Drittwirkung von Verfügungsverträgen rechtfertigt, indem er die Fälle, in denen dies möglich ist, gesetzlich beschränkt. Durch die Wahl eines der wenigen gesetzlich gestatteten Verfügungsvertragstypen führen die Vertragsparteien mittels der Regeln der Priorität und des Sukzessionsschutzes Wirkungen auch für solche Verträge herbei, an denen sie nicht beteiligt sind, nämlich sowohl nachfolgende Verpflichtungs- und Verfügungsverträge als auch vorangehende Verpflichtungsverträge.

Zweifellos kennt das Privatrecht noch andere Mechanismen, vertragliche Rechte und die damit verbundenen Interessen mit Drittwirkung auszustatten. Diese sind häufig an Elemente der Publizität wie den unmittelbaren Besitz gebunden oder werden aus Treu und Glauben hergeleitet. Obwohl diese Mechanismen eine ähnliche Wirkung wie der Grundsatz des Numerus Clausus entfalten und diesem häufig sogar entgegengesetzt erscheinen, kann nicht von dessen Abschaffung die Rede sein. Nach richtiger Auffassung handelt es sich um verschiedene Rechtsfiguren, die folglich unterschiedliche Methoden erfordern. Diese Unterschiede betreffen den dritten und letzten Aspekt des Numerus Clausus-Prinzips, den diese Dissertation behandelt. Dafür werden zwei aussagekräftige Entscheidungen aus der brasilianischen Rechtsprechung untersucht. Dabei wird deutlich, dass innerhalb desselben Systems zwei verschiedene Grundsätze des Vermögensrechts koexistieren können, dass aber der Numerus Clausus der dinglichen Rechte weiterhin das tragende Prinzip des brasilianischen Verkehrsrechts ist. 


\section{ABSTRACT}

\section{NUMERUS CLAUSUS OF PROPERTY RIGHTS AND PRIVATE AUTONOMY IN EXCHANGE CONTRACTS}

My dissertation focuses on a legal regime generally referred to as "numerus clausus of property rights". It does so by examining three main aspects of the theme.

First of all it analyses the function of that legal regime, which is the source of its perceived legitimacy nowadays. This function consists in tendering for buyers a welldefined catalogue describing all the possible agreements concerning the goods they intend to buy and that are going to be considered as burdens. In a Private Law system, which fosters the private autonomy and prearranges burdens, the numerus clausus works as a menu of those contracts likely to create burdens. All the other contracts not listed in that menu even if they make reference to certain goods will not be treated as burdens. Thus, the buyer may know that his own interests over these goods will not be affected.

Second the dissertation identifies a positive and a negative quality in this function. A possible negative aspect is that the numerus clausus is a heavy limitation to private autonomy, mainly to exchange contracts. In this sense, not only the exchanges involving property interests (rights in rem) but also those affecting credits and other kinds of rights (rights in personam) are submitted to the same legal regime which leads to Private Law generally recognizing two kinds of private autonomy regimes in Contract. While in exchange contracts the autonomy is limited, in executory contracts the autonomy is sensitively wider. A possible positive aspect is that the numerus clausus establishes a very powerful tool for opposing interests to third parties: the exchange contract. By selecting one of the few exchange contracts available in that menu, parties may oppose their interests in future transactions they will not take part in. Exchange contracts are obviously not the only system available for opposing interests in Private Law. The so called good faith system, connected with publicity devices, works also in that way, but using a very different legal strategy. Although the legal doctrine is used to identify the application of the good faith system with a "realization" of personal rights, that seems problematic. As a 
matter of fact, as different legal conceptions, exchange contracts submitted to a numerus clausus regime and good faith system require different techniques and arguments.

These different procedures are discussed in the third section of my dissertation. In this section I discuss major cases in Brazilian Law which apply sometimes the numerus clausus systems and sometimes the good faith system. I argue that there is no contradiction between the both fashions of judicial decision, unless one simply uses the incoherent notion of "realization". 


\section{PALAVRAS-CHAVE}

Propriedade e direitos reais

Contratos e negócios jurídicos de disposição

Tipicidade e autonomia contratual

Oponibilidade das posições contratuais a terceiros-adquirentes

Realização das posições obrigacionais e boa-fé

\section{SCHLAGWÖRTER}

Eigentum und dingliche Rechte

Dingliche Verträge und Verfügungsgeschäfte

Typengebundenheit und Vertragsfreiheit

Drittwirkung der vertraglichen Rechtstellungen

Verdinglichung obligatorischer Rechte und Treu und Glauben

\section{KEY WORDS}

Property and rights in rem

Exchange contracts and Conveyances

Numerus Clausus and Private Autonomy

Opposable interests to buyers

Obligations in rem and Good Faith 